Discussion Paper No. 10-046

Total Costs and Budgetary Effects of Adaptation to Climate Change:

An Assessment for the European Union

Daniel Osberghaus and Christiane Reif

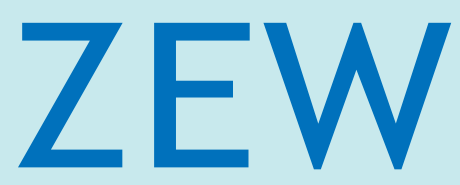

Zentrum für Europäische Wirtschaftsforschung $\mathrm{GmbH}$

Centre for European

Economic Research 
Discussion Paper No. 10-046

\section{Total Costs and Budgetary Effects of Adaptation to Climate Change: An Assessment for the European Union}

Daniel Osberghaus and Christiane Reif

Download this ZEW Discussion Paper from our ftp server:

ftp://ftp.zew.de/pub/zew-docs/dp/dp10046.pdf

Die Discussion Papers dienen einer möglichst schnellen Verbreitung von neueren Forschungsarbeiten des ZEW. Die Beiträge liegen in alleiniger Verantwortung der Autoren und stellen nicht notwendigerweise die Meinung des ZEW dar.

Discussion Papers are intended to make results of ZEW research promptly available to other economists in order to encourage discussion and suggestions for revisions. The authors are solely responsible for the contents which do not necessarily represent the opinion of the ZEW. 


\section{NON-TECHNICAL SUMMARY}

Adaptation to climate change is gaining increasing relevance in the public debate of climate policy. Thus, knowledge of costs and benefits of adaptation measures is of high importance. This study compiles existing cost estimates for adaptation measures in Europe. The systematic approach of the literature review points out sectoral and regional knowledge gaps in the adaptation research as well as high uncertainties. In particular, adaptation costs for the transport and human health sectors are scarce, although high adaptation costs can be expected in these impact sectors in the next decades.

Based on the literature review of adaptation costs, the study furthermore asks how and to which extent public budgets are affected by adaptation - an issue which has been broadly unexplored by existing literature to date. At first, we analyse qualitatively by which channels adaptation influences the public budgets. In the next step, we present theory-, literature- and data-based guesses for the public shares of total adaptation costs in each of the most affected economic sectors. Linking these shares with the literature-based cost estimates allows a first insight into the magnitude of future public adaptation expenses by sector.

The results are reflecting the high uncertainties and large knowledge gaps inherent in economic impact analyses of climate change issues. However, some conclusions can be drawn: High public costs may mainly be expected in flood protection and the transport sector. The annual costs for adaptation to climate change may amount to up to 4 bn $€$ in the 2060s, and 5.7 bn $€$ in 2050, respectively. In the agriculture sector higher total adaptation costs may occur, albeit paid by the public purse only to a minor degree. On the contrary, negative adaptation costs (i.e. saved expenses due to adaptation) are also expected, particularly through less heating demand. These savings of expenses can reach the notable amount of 4.2 bn $€$ in 2050, although with a high regional heterogeneity within Europe.

A synopsis of the findings reveals the need for further research in the quantification of adaptation costs and benefits as well as the high relevance of climate change adaptation for future public budgets in Europe. 


\section{DAS WiCHTIGSTE IN KÜRZE}

Die Anpassung an die Folgen des Klimawandels nimmt neben der Vermeidung von Treibhausgasen eine immer wichtigere Rolle in der Debatte um den Klimawandel ein. Aussagen über Kosten und Erlöse von Anpassungsmaßnahmen sind daher von großer Bedeutung. Diese Studie führt vorhandene Literatur über Kostenschätzungen der Anpassung in Europa zusammen und zeigt dabei sektorale und regionale Wissenslücken auf. Beispielsweise sind nur sehr wenige Kostenschätzungen in den Sektoren Verkehr und Gesundheit vorhanden, obwohl Europa erwartungsgemäß hier in den nächsten Jahrzehnten mit hohen Anpassungskosten konfrontiert sein wird.

In einem zweiten Teil befasst sich die Studie als eine der ersten Arbeiten mit den Auswirkungen von Anpassungsmaßnahmen auf die öffentlichen Haushalte in Europa. Zunächst werden in einer qualitativen Analyse die unterschiedlichen Wirkungskanäle von Anpassung auf die Staatsbudgets aufgezeigt. Darauf aufbauend werden theorie-, literatur- und datengeleitete Einschätzungen für einen staatlichen Anteil der gesamten Anpassungskosten in den am meisten betroffenen Wirtschaftssektoren gegeben. Eine Kopplung dieser Staatsanteile mit den im ersten Teil zusammengestellten Ergebnissen der Literaturrecherche ermöglicht die teilweise Abschätzung von öffentlichen Ausgaben, die in den nächsten Jahrzehnten in Europa für die Anpassung an den Klimawandel nötig werden.

Die Ergebnisse sind geprägt von der hohen Unsicherheit, die in der Analyse ökonomischer Folgen des Klimawandels immanent ist. Jedoch kristallisieren sich einige Schlussfolgerungen heraus: Öffentliche Kosten für Anpassung an den Klimawandel entstehen v.a. in den Sektoren Küstenschutz und Verkehr (bis zu 4 Mrd. € p.a. in den 2060ern bzw. bis zu 5,7 Mrd. € im Jahr 2050). Im Agrarsektor können u.U. höhere Kosten entstehen, die jedoch größtenteils privat getragen werden. Negative Anpassungskosten (d.h. durch Anpassung eingesparte Ausgaben) können durch eingesparte Heizkosten in beträchtlicher Höhe (bis zu 4,2 Mrd. € im Jahr 2050) auftreten, wobei hier in Nord- und Südeuropa sehr unterschiedliche Effekte erwartet werden. Im Gesamtbild zeigt die Analyse einen hohen Forschungsbedarf im Bereich der Kostenabschätzung von Anpassungsmaßnahmen an den Klimawandel und die hohe Relevanz des Themas für die öffentlichen Haushalte. 


\title{
Total Costs and Budgetary Effects of Adaptation to Climate Change: An Assessment for the European Union
}

\author{
Daniel Osberghaus ${ }^{\mathrm{a}}$, Christiane Reif \\ (ZEW Mannheim)
}

July 2010

\begin{abstract}
Adaptation to climate change is gaining increasing relevance in the public debate of climate policy. However, detailed and regionalised cost estimates as a basis for cost-benefit-analyses are rare. We compose available cost estimates for adaptation in Europe, and in particular Germany, Finland and Italy. Furthermore, a systematic overview on fiscal aspects of adaptation is provided, with focus on budgetary effects of adaptation in the different impact sectors. Combining cost estimates, considerations on fiscal aspects and governmental interventions in adaptation processes, we present data-based guesses of public adaptation costs in the EU, divided by impact sectors. The findings show an expectedly large public burden in the adaptation of transport infrastructure and coastal protection, while high adaptation costs in the agriculture sector are predominantly private. The change in energy demand may well lead to a significant decrease in public expenditure. Considering the regional heterogeneity of adaptation measures and the high uncertainty of quantitative adaptation analyses, further research in the form of bottom-up-studies is needed.
\end{abstract}

Keywords: adaptation, climate change, adaptation costs, fiscal effects, governmental intervention.

JEL classification: H54, Q54, Q58

Acknowledgements: Funding by the European Commission under the framework contract ECFIN/E/2008/008 (“The Fiscal Implications of Climate Change Adaptation”) is gratefully acknowledged.

\footnotetext{
${ }^{\text {a }}$ Corresponding Author: Daniel Osberghaus, Centre for European Economic Research (ZEW Mannheim), email: osberghaus@zew.de, phone: +49 (0) 621-1235-205. P.O.Box 103443,68034 Mannheim, Germany.
} 


\section{INTRODUCTION}

Beside the mitigation of greenhouse gases, adaptation is another way to respond to climate change. The IPCC defines adaptation as the "Adjustment in natural or human systems in response to actual or expected climatic stimuli or their effects, which moderates harm or exploits beneficial opportunities.” (IPCC 2007, p. 869). Although this definition has its strength in the inclusion of both observed and expected climate change, as well as covering both positive and negative climate impacts, it also leaves some open questions. In particular, when applying the definition to observed activities, it often remains unclear whether activities are solely attributed to climatic stimuli. It may also be the case that structural changes, economic development, changes in risk perception or other non-climate-related triggers play a role. This fundamental problem of defining adaptation may be one main reason for the current scarcity of quantitative data on adaptation measures and their costs.

Adaptation can be classified according to the actors and the time horizon. In the according literature we find the expressions private, individual, decentralised or autonomous adaptation for such adaptation measures which constitute private goods and are regularly taken by private actors (Mendelsohn 2000, Fankhauser 1998, OECD 2008). The existence (and in some impact sectors the predominance) of private adaptation options reveals one main difference to mitigation efforts, which are characterised by the existence of large-scale public interventions (Tol 2005). But there are also adaptation measures which call for collective action, since beneficiaries and decision makers are not totally identical. There are different expressions to be found in the literature, with different accentuations. Joint and collective adaptation highlight the difference to private adaptation and the need for collective action (which can principally be organised by privates), whereas planned, governmental and public adaptation imply that these activities are taken by some governmental entity (Mendelsohn 2000, IPCC 2007, Dannenberg et al. 2009, Smith et al. 2009). Regarding the time horizon, one can distinguish proactive and reactive adaptation (Fankhauser 1998). The former means adaptation to expected future climatic changes, whereas the latter reacts to observed climate change.

This paper focuses on the fiscal effects of adaptation to climate change. Beside adaptation induced effects, climate change has other fiscal implications, like public spending for mitigation efforts, the implementation and use of fiscal instruments in climate policy, or reduced tax revenue due to productivity losses in the economy. Concentrating on adaptation, we will proceed as follows: In the next section we will summarise available cost estimates for adaptation measures in Europe. The fiscal aspects of adaptation will be analysed and 
categorised in section 3, followed by an argumentation where public involvement in adaptation is reasoned. After laying the theoretical and empirical ground, we will then draw conclusions regarding the direct fiscal adaptation costs in various impact sectors in Europe in section 4.2. Section 5 summarises the main findings.

\section{Adaptation Costs in Europe - A Literature ReVIEW in Matrix Format}

We compile the results from a literature review on adaptation costs in Europe, all in p.a.values in $€$ in prices of 2005. Beside studies covering all of Europe, we also include quantitative estimates for three exemplary countries from different climatic zones, namely Finland, Germany and Italy. Thereby we also show research foci and knowledge gaps and present the current state of research with regard to adaptation costs in Europe, in both bottomup and top-down studies.

Studies focussing on the vulnerability to climate change mostly incorporate adaptation needs and often stress the case for a proactive, precautionary climate policy which includes adaptation. However, although most scholars propose a cost-benefit-approach to find the optimal adaptation path, the knowledge of concrete adaptation costs is limited, as can be seen by many empty gaps in the matrix. Furthermore, results base on different scenarios and time horizons.

It should be stated that almost all data and estimates are direct adaptation costs, which do not include indirect costs resulting from forgone profits or feedback effects on consumption due to altered investment and consumption behaviour (opportunity costs). Only very few studies try to give an insight into these effects, for example Bosello et al. (2007) through a CGE approach. These indirect effects might be considerable in many cases. Unfortunately, the current state of research does not allow a reasonable statement concerning indirect effects. So we are forced to focus on direct adaptation costs which result from simple investment or maintenance costs.

For the detailed matrix and more information on it, e.g. about annualisation, exchange rates and inflation, we refer to the appendix of this paper.

\section{FISCAL AND BUDGETARY IMPLICATIONS OF ADAPTATION - AN OVERVIEW}

The differentiation between "fiscal" and "budgetary" is crucial to determine the scope of this paper. Before turning to budgetary effects in detail, it has to be clarified how they can be structured and how they are related to the frequently used term "fiscal implications". 
Fiscal policy means governmental action to influence the economy by public expenditure and income (Mankiw 2003). This means fiscal implications encompass both fiscal instruments to pursue certain policy targets as well as effects on the government's balance. In the literature, we can find mainly two different concepts of the terms "fiscal implications" or "fiscal effects”. Some authors refer to impacts that fiscal policy has on other variables (e.g. fiscal effects on mortgage debt or independence of the central bank; see Bell and Wray 2002, Wolswijk 2005). These concepts highlight the importance of fiscal instruments in the fiscal implication analysis. However, most authors understand fiscal effects as an impact of an exogenous variable (some policy, some shock or a gradual development) on the government's expenditure and revenue, so the main focus is actually the effect on the government's budget (e.g. Matsusaka 1995, Swaroop et al. 2000, Storesletten 2000). To make the difference between these two concepts clear, we will refer to the latter as analysis of "budgetary effects" instead of using the term "fiscal". In contrast to the definition of fiscal policy, the concept of budgetary effects neglects the targets pursued by the fiscal policy and solely analyses changes in government's expenditure and revenue flows. Likewise, in this contribution we will stick to this concept and focus just on the budgetary effects of adaptation to climate change. Fiscal instruments related to adaptation are not of relevance for this paper and remain an issue of future research.

The sign of the total impact of adaptation on the public budgets is not clear. Compared to a baseline scenario with climate change but without adaptation, it can be positive as long as adaptation yields net benefits (mainly in the form of reduced or avoided damages) and thereby increases the total economy's productivity. But if, where, when and to which extent these benefits occur, is by no means certain (Heal and Kriström 2002, Patt et al. 2009, World Bank 2009). Given the high uncertainty of future climate impacts the total budgetary effects of adaptation may also be negative, even when benefits of adaptation are taken into account. As an example think of the construction costs of a dike in expectation of a rising sea-level, and after the construction it turns out that the sea-level does not rise to the expected extent.

As a first step to assess budgetary effects, this contribution will concentrate on the effects of adaptation costs, mostly ignoring the benefits. This basically has two reasons: First, the magnitude of benefits is highly uncertain (Patt et al. 2009, World Bank 2009). While there are quite reasonable estimates of adaptation benefits for some specific adaptation measures (Bosello et al. 2009), the potential of mitigating climate damage of most measures is very uncertain. An example is adaptation of infrastructure which can make up to two thirds of global adaptation costs in 2030 (UNFCCC 2007). The benefits of these activities hinge on 
several unknown factors like future frequency and severity of extreme weather events and the effectiveness of technical measures to adapt buildings. Also the well-developed research field of agricultural adaptation does not give a clear answer regarding the effectiveness of adaptation. Estimates of the adaptation effectiveness have a great variance (IPCC 2007, p. 286). Hence, an economy-wide comprehensive quantitative analysis of adaptation benefits is not applicable by now, which suggests focussing on adaptation costs.

The second reason comes from the intertemporal heterogeneity of adaptation. One can assume that costs arise today, whereas most benefits occur in later periods (Fankhauser et al. 1999, Mendelsohn 2000). The same holds true for negative and positive budgetary effects, respectively. Although public budgets can comparably easily smooth income over time, the short term balance of public budgets is still an issue of interest, at least in the face of the European stability and growth pact, which i.a. schedules a procedure in order to prevent excessive deficits (more than 3\% of GDP) in the Euro-area (European Council 1997). Therefore, the short term budgetary impacts of adaptation costs are indeed of interest, even in the absence of a comprehensive long-term-oriented cost-benefit-analysis.

We will furthermore restrict our analysis to an aggregate view of public budgets. In Europe there are authorities on multiple levels with specific budgetary responsibilities and characteristics. Determining which federal level is in charge for which policy measure is rarely an easy task (see e.g. Farber 2009 as a contribution with regard to adaptation). For the different public actors, like municipalities, states, countries or supranational communities it matters on which level the responsibility is taken. These questions often give rise to controversial debates. However, we will view the public planner as one, neglecting these issues of federal division of responsibilities, in order to get a first insight into the budgetary effects connected to adaptation. After this first step, the disaggregation into the relevant fiscal levels would be an essential task for future research.

Impacts on the government's budget due to adaptation can be disentangled in direct and indirect effects (or first and second round effects). Direct effects mainly affect government's expenditure, and result e.g. from public investments in adaptive infrastructure or subsidies for private adaptation measures. These expenditures are surely the most obvious and visible budgetary effects, though they do not have to be the highest. Many will think of rising expenditures, like additional investment in dike construction or in transport infrastructure. However, one can also think of declining expenditures, e.g. in the field of heating energy for public buildings or winter road maintenance. Though these measures do not constitute new activities, the reduction of these services can also be defined as adaptation in the sense of the 
IPCC definition (IPCC 2007, p. 869). The direct net effect of adaptation is therefore difficult to predict theoretically, but the results of a literature review presented in part 2 of this paper suggest clearly negative impacts on public budgets in Europe. Even more can be expected for other countries, as climate damages are relatively higher in many non-European countries.

Indirect effects, in contrast, become relevant when adaptation (whether private or public) as a side effect changes the tax revenue. To highlight the potential importance of indirect budgetary effects, we will have a brief look at the results of Bräuer et al. (2009), who analysed budgetary effects of climate change (not only adaptation) in Germany. The authors conclude that the indirect effects on public budgets - like reduced tax revenues - may amount to approximately $87 \%$ of the total. For the case of adaptation the net budgetary impact of these second-round effects is not obvious. We will disentangle the indirect effects in the subsequent sections.

In basic economic theory, it is assumed that companies adapt only if adaptation increases their profitability (see e.g. Mendelsohn 2000, OECD 2008). Compared to a scenario with climate change but without adaptation, the simplifying assumption of efficient adaptation suggests a clearly positive impact on tax revenue. However, considering timing, uncertainty and other sources of inefficiency, net effects on the public budgets may also be negative. Short-term negative impacts may arise from adaptation measures which cost (and thereby reduce the taxable income) today, while the benefits may only occur in the long run (Fankhauser et al. 1999). Uncertainty of future climate impacts and consequently of the effectiveness of adaptation yields further risks of costs exceeding benefits even in the long run (Mendelsohn 2000, OECD 2008). Moreover, myopic behaviour of companies and individuals as well as financial constraints may hamper efficient adaptation processes. If these drawbacks reduce the company's overall productivity, the tax revenue also tends to decline.

So far we only considered the impact on the company-level. We will now turn to the total economy. As company resources are limited, funds that have been spent for any non-adaptive activity $X$, must now be spent on adaptation (activity $A$ ). Effectively, demand shifts from the sector providing activity $X$ to the sector providing activity A. Given different effective tax rates for different sectors, the tax revenue may change due to a shift of production towards adaptation-oriented sectors (e.g. construction or manufacture). In other words, the sign of the indirect budgetary effects of autonomous adaptation hinges on the question whether production in the adaptation-oriented sector $A$ yields relatively higher or lower tax revenue than the sector $X$ where demand declines. 
Under certain conditions an adaptation-induced shift of production can also lead to changes in the sectoral employment, such that labour demand follows the demand shift. This, in turn, can have positive or negative impacts on the government's budget, depending on the sectorspecific labour market situation.

Further indirect effects may arise in the context of open economies. A country with a relatively high competitiveness in adaptation technologies will possibly gain earnings from a global increase of adaptation demand, and probably achieve higher public revenues. On the contrary, countries which import adaptation technologies and where adaptation demand crowds out domestic demand would feel additional pressure on their productivity and consequently budgets. ${ }^{1}$

Another aspect still has to be tackled: an important part of every binding international climate agreement, whenever it will be accomplished, will be payments of industrialised countries to developing countries. Estimates of the financial needs for adaptation in developing countries range from 27 billion USD p.a. around 2030 (UNFCCC 2007, aggregated by Parry et al. 2009) to more than 100 billion USD p.a. between 2010 and 2050 (World Bank 2009). The latter figure translates in almost a doubling of the current development aid, emphasising the tremendous magnitude of the task. These costs will undoubtedly go far beyond the capacity of the public budgets in the affected countries, so that at least parts of these costs may be borne by highly-developed countries. ${ }^{2}$ The additional burden will strain their public budgets, besides the effects of domestic adaptation. Note that the indirect effects of exported adaptation technology may mitigate the negative impacts (Mendelsohn 2000 mentions this phenomenon with a negative connotation).

In this section we gave a short overview on what fiscal implications with regard to adaptation may actually mean. First, we distinguished fiscal implications (which may incur budgetary effects as well as fiscal instruments and have to be seen in connection to policy targets) from sole budgetary effects. We furthermore described direct vs. indirect budgetary effects of adaptation and mentioned the probably high relevance of a binding international adaptation funding agreement. In the next section, we will deepen the analysis in one specific kind of budgetary effects, and introduce a method to reasonably guess the actual public burden of adaptation.

\footnotetext{
${ }^{1}$ However, the export of high technology based adaptation techniques always bears the risk of technology theft which may hamper the willingness of private companies to engage in international markets. This is not being considered here.

2 The reasons why highly-developed countries should finance adaptation in other countries partly ground in international equity rationales and partly arise from considerations of future international migration and trade
} 


\section{An Analysis of the Public Shares of Sectoral Adaptation Costs}

For the remainder of the paper we will focus on one specific part of the budgetary effects, namely direct expenditures for adaptive investments by the public sector. The reason for this limitation is mainly the current state of data. Although indirect effects may have a high relevance for the sustainability of public budgets, quantitative data are sparse or non-existent. However, though the limitation on direct expenditures may be a serious drawback in terms of budget forecast, it still allows the introduction of a method which is new in literature and gives first insights into possible budgetary burdens due to adaptation.

We will base our analysis on an approach firstly used by IMF (2008). The authors present expected public adaptation investments in some of the impact sectors by using absolute adaptation cost estimates by UNFCCC (2007) and applying rough sector-specific ratios of public engagement. We will develop this method further by including more impact sectors and introducing theoretically and empirically grounded determinants for public shares in each impact sector. In section 4.1, possible reasons for public intervention in adaptation processes are shortly identified, leading to a proposed public share of adaptation costs in section 4.2. Consecutively, these ratios combined with the adaptation costs from the literature give first quantitative insights into direct budgetary effects of adaptation to climate change. ${ }^{3}$

\subsection{Theory of public adaptation}

The differentiation of public and private adaptation is crucial for determining the budgetary effects of adaptation. In cases where the government takes the responsibility it may come to direct public expenditures. Governmental intervention into markets can be reasoned by (a) market failures, (b) equity aspects and (c) security of supply considerations. Budgetary effects can furthermore occur if governmental entities engage in economic behaviour like private shareholders.

developments. They are, however, not the topic of this paper. The point here is simply that remittances will add to the budgetary burden in developed countries.

${ }^{3}$ Due to a lack of detailed data, we could not use the cost estimates in the cross-sectoral impact sector "Extreme weather events". Admittedly, according to the literature review the highest adaptation costs may be expected there. But as there is no information available which actors are affected by these costs and how exactly the costs arise, it is to date not possible to determine the specific degree of governmental affection. Therefore the used methodology can not be applied here. 
Market failures occur when perfect market conditions are violated and inefficient allocations of goods and services are the outcome. This is in line with the definition by Bator (1958), where an idealised system of price-market institutions fails to sustain desirable consumption or production activities. Putting it the other way around market efficiency means that competitive market solutions will lead to Pareto efficient solutions.

The reasons for market failure are imbalanced market power, incomplete information, externalities or public goods issues. In environmental economics as well as adaptation processes especially the two last aspects can become relevant. Based on the description of Cornes and Sandler (1986) externalities are defined as actions of an individual or a producer, which have a positive or negative effect on other parties outside the certain market and are not internalised. In case of adaptation external effects can occur if individuals or one group adapt to climate change and these measures affect others. Private adaptation in the agricultural sector can serve as an example: If a farmer adapts to dryer weather conditions due to climate change by implementing an irrigation system and therefore taking ground water, the ground water level sinks and that may lead to lacks in other locations which may harm nature or human activities. The action of the farmer has therefore external effects, which justifies governmental intervention in adaptation.

Public goods can be categorised as a special case of externalities (Bator 1958, Buchanan and Stubblebine 1962, Cornes and Sandler 1986), and are regularly provided by the government. Pure public goods contain two central qualities namely non-excludability and non-rivalry in consumption (Cowen 1988, Pindyck and Rubinfeld 1998), basing also on Samuelson's theoretical framework (1954). An example with regard to adaptation processes is the implementation of early-warning-systems with publicly issued warnings. Another important example facilitating adaptation processes is the building of a knowledge base and dissemination of information on climate effects.

However, non-excludability and non-rivalry in consumption with regard to public adaptation goods is not always fully given. The impacts of climate change are mainly on a regional or local level and therefore the adaptation measures benefit only a part of the population. Dykes protect only the people who live in areas in which floods are a likely risk. Therefore they are called local public goods. An efficient outcome of publicly taken adaptation measures on pure or impure public goods requires the cooperation of local, regional and national governments as well as supranational entities. 
Equity aspects can justify government intervention even in the absence of market failure. Equity principles can be differentiated into horizontal and vertical fairness (Atkinson and Stiglitz 1980). Horizontal equity refers to the equal treatment of individuals, but if viewed on a national perspective horizontal equity can easily be extended to the equal treatment of regions or agglomerations. Vertical equity considers the different abilities to afford adaptation measures.

Adaptation processes solely based on cost efficiency may not be considered as just (Mendelsohn 2000). For example the protection of one region from floods may be worth on cost-benefit criteria but for another region this might not apply. Horizontal equity, in contrast, would call for an equal treatment of both regions (and ultimately their inhabitants and users). Vertical equity would give case for the support of citizens in need which cannot afford certain adaptation goods. This shows that decisions based on pure cost-efficiency may well interfere with equity targets of the society.

However, governments take the responsibility for adaptation measures of basic needs - even if they are not cost efficient - to ensure a minimal level of care for inhabitants in need. In social welfare states this is reasoned by the democratic voting process, where the voters can put pressure on the parliament. But also supranational regulations take social rights into account and demand from the countries social justice (see International Covenant on Economic, Social and Cultural Rights, GA resolution 2200A). In any case the pursuing of horizontal and vertical equity will call for governmental intervention into adaptation processes and thereby increases the fiscal effects.

The governmental task to secure the supply of special goods is another reason for public action. The focus lies on elementary goods and services such as food, water and energy. All these sectors will have to adapt to changing climate, in due consideration of a secure supply. The energy sector is a special case for concerns about the security of supply and plays an important role in policy (Abbott 2001, Helm 2002, Barreto and Turton 2005). Beside network securities the diversification of energy resources and ensuring fairly and stable prices for investment decisions are aspects of security of supply within the energy market (Helm 2002). The security of supply has to be differentiated from pure supply issues, because the guarantee of supply is an additional service which may have characteristics of a public good (Abbott 2001). Governmental action can proof as necessary to secure the provision of the goods itself and to secure the delivery. Water and energy transmission systems are typical examples where network externalities occur and a monopolistic provider can offer the service at lower costs 
than a competitive market. Therefore governments regularly intervene by regulating prices. However, they intervene even beyond market failure rationales. The value of a secure supply itself is seen as a reason for setting legal frameworks and other interventions which foster an enduring supply of elementary goods. The Federal Network Agency in Germany serves as an example. This public institution not only regulates transmission prices, but also commits network operators to ensure an uninterrupted supply. Another example is the provision of drinking water during an extreme drought. The scarcity will lead to higher prices due to their price inelasticity at least in the short run. Although this will lead to market clearance and efficient outcomes, this might be unacceptable concerning public welfare. From this point of view, public action is required to ensure the satisfaction of basic human needs.

In addition to fulfilling the tasks of a social planner in the case of market failure and for reasons of equity and security of supply, the government may engage economically in impact sectors. Like private foresters, energy suppliers and house-owners, the government may act in these markets as a profit-oriented market actor, which will have considerable effects on the public budgets. An obvious example is the ownership and maintenance (heating and cooling) of public buildings like schools and public administration buildings. But governmental engagement in economic processes also occurs in the forestry sector (government as owner of forests) and in energy supply (publicly owned transmission system operators).

It should be noted that the analysis of budgetary effects through public ownership is totally different from the argumentation of governmental intervention in social planner tasks. While in the first case the government behaves basically as a private market participant; in the latter case it acts based on its sovereignty. In the first case it finances its activities by income reflecting the costs (at least this is principally possible); in the latter case the intervention is financed by tax revenue. However, both public activities cause budgetary effects and will therefore be examined commonly in this analysis, although their nature is so different. For the interpretation of results later on, it should be kept in mind that costs arising from public ownership may be “outsourced” (i.e. privatised) more easily than social planner tasks. Since these developments are hard to predict, we will base our analysis on the conditions found today. 


\subsection{Proposal of Public Shares per Sector}

\subsubsection{Agriculture}

The estimates in literature have a large range. Fischer et al. (2007) propose adaptation costs only for irrigation amounting to 161 to 966 million $€$ p.a. in Western Europe in 2030, based on different scenarios, with rising costs post 2030. Bosello et al. (2009) estimate a much larger value of 6,274 million $€$ p.a. for irrigation in Western Europe in the 2060s. Governmental intervention, especially long-run structural changes, has a variety of reasons. The first one to be mentioned is the interaction between mitigation and adaptation. Certain adaptation measures may not be conducive to mitigation. Changing cultivation or livestock production techniques can lead to increasing GHG emissions. Economic efficiency would require a price setting on these emissions. A task of the government is to set frameworks and support adaptation strategies, in which the interactions are taken into account. The second reason for governmental intervention is facilitating of autonomous adaptation. The long-term adaptation measures show that distribution of information and provision of a regulative framework are the basis for private adaptation. This includes primarily knowledge about effectiveness of adaptation measures and the expected impacts of climate change, as well as regulation of property rights and tenancy rules. Another cause for the government to intervene is equity. Adaptation has the potential to become very costly. Especially countries, where agricultural production has a large share of the GDP, adaptation costs could lead to negative effects on its national or regional welfare. Also in the EU, where the economic importance of the agricultural production is relatively low, there are differences between the member states. Countries with a lower per capita income, particularly new member states, show a higher dependency on agriculture than richer member states. Moreover, the impacts of climate change may benefit Northern Europe while the Southern member states are rather disadvantaged. Therefore intergovernmental transfers would help to balance the inequalities. Equity aspects also play a role within one country. The provision of emergency relief after extreme weather events by the government can be justified, if farmers cannot afford proper insurance or the possible damages are not insurable at all. Furthermore, the security of food supply is also a topic for governmental adaptation policy. If one good is essential, the government should guarantee the security of supply. When it comes to food the decision about which types of crops are indispensible and to what extent the government should ensure the food supply is crucial. The attempt to quantify the shares of public expenditures to climate change adaptation in the agricultural sector is challenging. The majority of adaptation measures is autonomous. However, considering planned adaptation, equity and security of 
supply aspects the expenditures are not entirely private. According to global estimations by IMF (2008) the public share of adaptation expenditures within agriculture, forestry and fishery is around 15\%, which can be justified by our theoretical considerations. This translates into absolute values of approximately 940 million $€$ p.a. only for irrigation in Western Europe in the 2060s; respectively 25 to 145 million $€$ p.a. only for irrigation in Western Europe in 2030, based on different scenarios, with rising costs post 2030.

\subsubsection{Forestry}

There are no specific data available about adaptation costs in the European forestry sector, so cost estimations and public expenditures cannot be numerically presented. Adaptation to climate change impacts in the forestry are mainly precautionary measures, such as the implementation of early warning systems, diversification of tree types and transformation to other tree types. The central characteristic of adaptation measures in the forest sector is their long anticipatory time horizon. Long growing periods and the relative impossibility of retrofitting call for early action. The government acts on the one hand as a social planner, who provides knowledge transfer and research issues as well as early warning systems. Furthermore it takes positive externalities of forests into account. These are for instance their $\mathrm{CO}_{2}$ compensation capacities, their positive effects on regional microclimates, on biodiversity and on local recreation. Finally, the state is owner of forests itself. The average share of total public ownership weighted by the production size is around $40 \%$ (own calculations based on Eurostat data). The shares in the different member states vary largely, such that a European mean value (even a weighted one) has to be interpreted with caution. This ownership approach can only serve as a first assessment about public shares of adaptation expenditures. Together with actions as a social planner, the actual share of total adaptation costs is somewhat higher than the ownership share. We propose a share applicable in Europe of around $45 \%$.

\subsubsection{Flood Protection}

Summarised, the cost estimates for flood protection measures in Europe amount to annual costs of 281 to 4,022 million $€$ for coastal protection in the EU, assuming different scenarios regarding sea level rise. Flood protection is a prime example for a public good. It resembles a form of joint adaptation which has to be provided by collective action and in most cases will be organised and financed by a governmental entity. Translated into budgetary effects, that means most (if not all) of the adaptation costs will be borne by public budgets. However, 
assuming a public share of $100 \%$ of flood protection costs may be slightly overestimated, because some EU member states share the financial burden of flood protection with private actors (Policy Research Corporation 2009). After a review of the different funding regulations for coastal protection in the EU, we propose a public share of around $98 \%$. That means, the public costs amount to 275 (in 2050, EU) to 3,950 million $€$ (2060s, Western Europe), depending on the underlying sea level rise scenarios and assumptions.

\subsubsection{Water Supply}

Adaptation costs in the impact field of water supply are estimated at 251 to 875 million $€$ in European OECD countries in 2030 (UNFCCC 2007); and 2,655 million € p.a. in Western Europe in the 2060s (Bosello et al. 2009). Governmental intervention in the water supply sector is mainly based on two rationales: First, networks for sewage or water supply create increasing returns to scale. The other is grounded in security-of-supply rationales. Obviously, water is an indispensible good for any economy of the world, which gives a strong case for governments to ensure the secure supply even under new conditions like climate change. For these reasons one can also expect direct governmental action to ensure drinking water supply in times of extreme droughts. Based on these considerations, we propose a public share of adaptation investment costs in the water supply field. Bräuer et al. (2009) assume a share of $25 \%$ for Germany, which seems to be reasonable since great parts of the investment costs are refinanced by usage fees, so ultimately by private actors. However, public resources are still strained, for the abovementioned reasons of governmental interference. Due to a lack of detailed data of other EU member states, we assume the same portion to be realistic for the total EU. The budgetary effects of adaptation in water supply and sewage systems will therefore add up to approximately 60 to 220 million $€$ p.a. in European OECD countries in 2030, and 665 million $€$ p.a. in Western Europe in the 2060s, based on different scenarios.

\subsubsection{Health}

In Western Europe, global warming could decrease total health expenditure by 563 million $€$ p.a. in 2060-2065, as net effects of adverse temperature effects and a decrease of expenditures for cold-related diseases (Bosello et al. 2009). Contrary, in Eastern Europe and the former Soviet Union adaptation of the health infrastructure could cause costs in the same order in the first half of the century (World Bank 2009). A great part of the adaptation related to health is taken autonomously, e.g. cooling homes and other behavioural changes. However, collective adaptation tends to cause higher costs. It is characterised by e.g. the provision of 
infrastructure, dissemination of information, research and monitoring of climate change related diseases. The free market normally does not provide these goods, so these measures are mainly taken by the government and therefore cause public expenditures. Furthermore, when it comes to the provision of equal access to health care equity aspects play a role. On the one hand geographical distribution of medical care which means the number and distribution of physicians across the country is necessary to ensure equal access. On the other hand guaranteeing that the services are affordable for everyone is essential under equity aspects. Due to the lack of data about specific adaptation expenditures in the health sector we use the current public share of total health care expenditures as a proxy. The EU-wide public share weighted by total expenditures was around 77\% in 2005 and 2006. Taking into account an ageing society and higher requests to the public infrastructure (e.g. heat wave early warning systems) we propose a slightly higher public share of ca. $80 \%$. This means, public budgets in Western Europe are possibly unburdened by 450 million $€$ p.a. in the 2060s (Bosello et al. 2009), whereas other literature suggests additional public costs in Eastern Europe of the same amount in 2010-2050 (World Bank 2009).

\subsubsection{Energy Supply}

The energy industry plays a central role in the climate change debate. But most of the scientific and public discussion concerns mitigation in the energy sector. For adaptation, the literature suggests following cost estimates: 563 million $€$ p.a. in the 2060s for undefined adaptation measures in Western Europe; 1 billion $€$ in 2050 for cooling measures in thermal power plants in the EU27 plus Norway and Switzerland. Energy networks have always been regulated in some way due to network externalities. In the EU member states, the regulation itself is currently characterised by two slightly different strategies. In both alternatives the network is operated by a transmission system operator (TSO), which is separated from the generating companies (legally, by management or by ownership, see Sioshansi and Pfaffenberger 2006). Either the TSOs are private companies, regulated by a governmental authority (e.g. the Federal Network Agency in Germany), which sets price ceilings or returnon-investment-ceilings. Moreover, TSOs are legally committed to secure an enduring energy supply. In the other alternative TSOs are publicly owned companies, as it is the case in most EU member states. In both cases TSOs should charge prices that ensure a cost-effective operation of the network, without any cross-subsidies. That means if budgetary costs rise due to some adaptation of energy networks by state-owned TSOs, these costs should be reflected by higher transmission fees ultimately charged from the consumer. So finally, from an 
economic point of view the end consumers will be affected and not the public purse, regardless of the ownership structure of the TSO. Another situation arises in the context of security-of-supply-considerations. No government would accept an enduring breakdown of power networks or even the danger of such an event. Budgetary effects may possibly arise if TSOs are not enough financially capable for the necessary investments in climate-proof grids, and ask for financial support. For ensuring the security of supply, power plants also have to tackle the problem of insufficient cooling water supply. If governments have a high interest in the secure supply also during large-scale heat waves, they might implement policies ensuring that power generators care for these events, which would then possibly cause expenses. Equity-related issues may affect the fiscal adaptation costs in the energy sector as well. Vertical equity considerations may call for higher public support of citizens in need if the energy retail prices rise because of climate adaptation. To sum up these aspects of governmental intervention in energy supply, we recognize the significant regulative interventions, but put the overall budgetary costs of adaptation on the energy supply side at not more than $5 \%$ of the total adaptation costs. Note that this guess is underlying the assumption of no cross-subsidising of the regular network operation. Combining this share with the available cost estimates, we conclude the following fiscal costs of adaptation in the energy supply: 28 million $€$ p.a. in the 2060s in Western Europe; around 50 million $€$ in 2050 in the EU27 plus Norway and Switzerland.

\subsubsection{Energy demand}

Adaptation of demand is likely to result in more demand for cooling and less demand for heating energy. Although this behaviour seems trivial and could be interpreted as a form of impact, it fulfils the criteria of a reactive adaptation measure, as defined by the IPCC (IPCC 2007). Therefore, it will be included in this analysis. Tol 2002 estimates a net effect of additional energy costs adding up to over 6 billion $€$ p.a. in European OECD countries (Tol 2002). Another study suggests net savings due to decreased heating needs and increased electricity needs for cooling of ca. 28 billion $€$ in 2050 in the total EU27 plus Norway and Switzerland (Jochem and Schade 2009). The large range of these figures highlights the immense uncertainty of available adaptation cost estimates. The various results cannot only be explained by differences in time horizons, spatial coverage and underlying scenarios; there remains a large amount of scientific and technological uncertainty. The effects are relatively high, compared to other adaptation costs, and vary strongly across Europe and among different studies. Budgetary effects of this adaptation behaviour may arise to the extent 
buildings are owned and maintained (heated and cooled) by governmental entities. Thus, the public share in the effect of demand adjustment hinges on the share of public buildings in the total building stock. Bräuer et al. (2009) estimate a ratio of public buildings over the stock of total buildings of $10 \%$ for Germany. An analysis of Eurostat statistics on fixed assets shows that the German value may serve as an approximation for the EU average (weighted by the total fixed assets), though the differences within Europe are high. For the aggregate of all EU members, a ratio of $10-15 \%$ seems reasonable, which means that $10-15 \%$ of the demand adjustment effect will affect the public budgets. Expressed in figures, this means that in the total EU energy costs may rise by 600 million $€$ to 1 billion $€$ p.a. due to the cooling of public buildings (Tol 2002). Contrary, basing on the study of Jochem and Schade (2009), there will be energy cost savings for the public purse amounting to 2.7 to 4.2 billion $€$ in 2050 . These values, however, underlie high uncertainty with regard to the technological development within the $21^{\text {st }}$ century.

\subsubsection{Transport}

In the transport sector, cost estimates range from 3 to 6 billion $€$ for the adaptation of infrastructure in the EU27 plus Norway and Switzerland in 2050 (Jochem and Schade 2009). Beside impacts on traffic safety, the infrastructure is the most critical issue in the transport sector. Governmental intervention in the transport sector is mainly reasoned by market failure issues. Road networks which are free of charge and open to the public constitute a public good. There are, however, roads and other transport infrastructure co-financed by user fees, but the bulk of transport networks in Europe (in terms of $\mathrm{km}$ ) are still free of charge, and mostly financed by the public sector. Furthermore privately owned roads and railways exist. Unfortunately, data of ownership structures is not available on the EU level. Knowledge about the private and public ownerships of the networks would provide a basis for an attempt to propose the government share of adaptation expenditures. Nevertheless, the share is expected to be high (we assume more than 90\%), due to high public engagement in the transport infrastructure. Even if there are possibilities to exclude users from road services and thereby introduce user-fees, governmental intervention may occur due to security-of-supply and equity rationales. If user-fee-based networks fail to provide an adequate quantity (e.g. distribution of airports or railway stations over the country) and quality (e.g. paved roads) of infrastructure, the government may step in to ensure the access to transport services for each region and each member of society in need. Thereby the public share of total adaptation investments may rise beyond the actual share of public network infrastructure. We assume 
95\%, admitting that this is a rough guess which can only serve as a first attempt to approach the actual public burden. This would translate in absolute budgetary costs of approximately 2.9 to 5.7 billion $€$ for infrastructure in the EU27 plus Norway and Switzerland in 2050.

\section{Conclusion}

In the previous sections we developed a method to valuate the direct budgetary effect of adaptation to climate change and gave data-based and informed guesses of public costs to be expected based on literature on adaptation costs. These numerical conclusions can only serve as a first rough insight into the fiscal effects of adaptation, ignoring indirect effects and covering only few impact sectors. Moreover, due to a lack of detailed data, we could not derive public costs in the cross-sectoral impact sector "Extreme weather events". Admittedly, according to the literature review the highest adaptation costs may occur there. But as there is no information available which actors are affected by these costs and how exactly the costs arise, it is to date not possible to determine the specific degree of governmental affection. Therefore, the used methodology could not be applied here. However, the results highlight certain impact fields with relatively high public costs, compared to others where the total adaptation costs may be high, but the public burden is expectedly low. Figure 1 depicts graphically the public burden in the different impact sectors. The comparability of the bars is limited, as the values are derived from different studies (including different methodologies, models, assumptions, time horizons and climate scenarios). Therefore we included the lowest and the highest cost value for each sector, so that the large range of possible outcomes is illustrated. Detailed information on underlying scenarios, time horizons and assumptions can be found in the literature review in matrix form in the appendix. The upper part of the figure shows the estimated adaptation costs, divided into public and private costs, as they appear in the matrix. Due to very high negative costs in the energy demand sector, the other entries are hardly visible. That is why we included the lower part of the figure, where the energy demand sector is dropped to increase the visibility of the other sectors. 
Figure 1: Direct public and private adaptation costs (upper part including energy demand, lower part without energy demand).
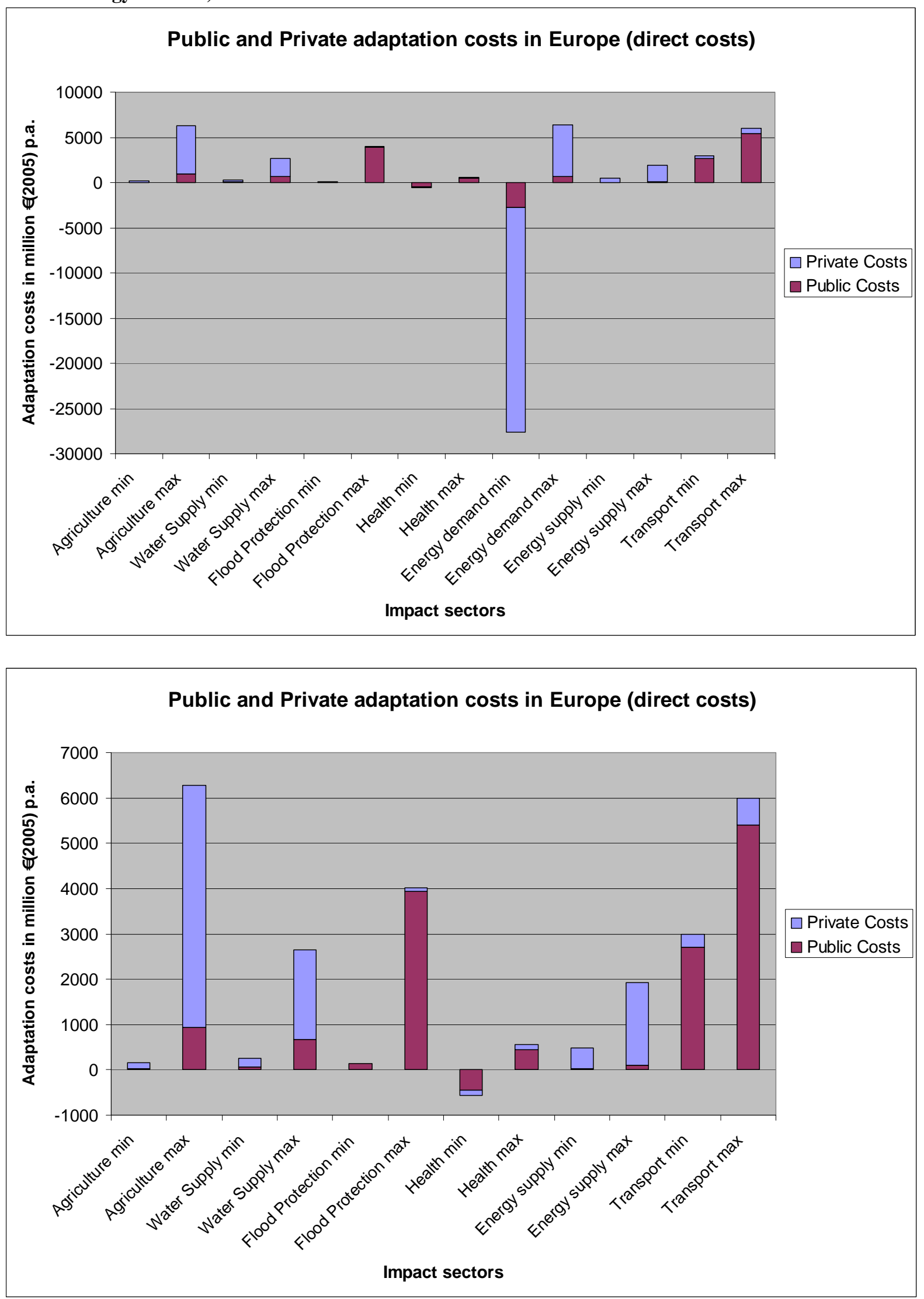

Direct budgetary costs due to adaptation are comparably high for transport infrastructure and flood protection. In other impact sectors (e.g. agriculture) adaptation may cause higher costs, 
but these are mainly financed by private actors. Direct effects due to energy demand are highly variable over regions (Jochem and Schade 2009, Eskeland and Mideksa 2009), so the figure for total EU (savings of up to 28 billion $€$ p.a.) has to be interpreted with caution. All cost estimates (including energy demand, transport and flood protection) are subject to high uncertainties with regard to climatic change scenarios and the future socio-economic development. E.g., the budgetary effect of flood adaptation is expected to be in the range between 137 million $€$ p.a. (EC12 without Eastern Germany, by 2100, basing on Fankhauser 1992) and 3,950 million € p.a. (Western Europe in the 2060s, Bosello et al. 2009), depending on the underlying assumptions and scenarios. Regarding the budgetary effects of adaptation of the health sector even the sign is not sure. Those high uncertainty ranges call for further quantitative research, in particular focussing on regional or local vulnerability heterogeneities. Although the uncertainty is still very high, this analysis can serve as a first, theory-grounded and reasonable insight of which sectors cause which magnitude of budgetary effects. 


\section{REFERENCES}

Abbott, M. (2001): Is the Security of Electricity Supply a Public Good?, The Electricity Journal 14 (7), 31-33.

Alberini, A., Chiabai, A. (2005): Urban Environmental Health and Sensitive Populations: How Much are the Italians Willing to Pay to Reduce Their Risks? Working Paper 105.2005, FEEM.

Atkinson, A.B., Stiglitz, J.E. (1980): Lectures on Public Economics, McGraw Hill, London.

Bator, F.M. (1958): The anatomy of Market Failure, The Quarterly Journal of Economics 72(3), 351-379.

Barreto, L., Turton, H. (2005): Long-term security of energy supply and climate change, Energy Policy, 34(2006), 2232-2250.

Bell, S. and Wray, R. (2002): Fiscal effects on reserves and the independence of the Fed, Journal of Post Keynesian Economics, Volume 25, No. 2, pp. 263-271.

Bosello, F., Bigano, A., Roson, R., Tol, R.S.J. (2007): Economy-Wide Estimates of the Implications of Climate Change: Sea Level Rise, Environmental \& Resource Economics 37, 549-571.

Bosello, F., Carraro, C., De Cian, E. (2009): An Analysis of Adaptation as a Response to Climate Change, Department of Economics, Ca’ Fosari University of Venice, Working Paper No. 26/WP/2009.

Bräuer, I., Umpfenbach, K., Blobel, D., Grünig, M., Best, A., Peter, M. and Lückge, H. (2009): Klimawandel: Welche Belastungen entstehen für die Tragfähigkeit der Öffentlichen Finanzen?, Endbericht, Ecologic Institute, Berlin.

Buchanan, J. M., Stubblebine, WM.C. (1962): Externality, Economica, 29(116), 371-384.

Carraro, C., Sgobbi, A. (2008): Climate Change Impacts and Adaptation Strategies in Italy: An Economic Assessment, FEEM Research Paper, Fondazione Eni Enrico Mattei.

Carter, T. R. (ed.) (2007): Assessing the adaptive capacity of the Finnish environment and society under a changing climate: FINADAPT, Summary for Policy Makers, Finnish Environment Institute (SYKE), Helsinki 2007.

Ciscar, J.-C. (editor) (2009): Climate change impacts in Europe, Final report of the PESETA research project.

Cornes, R., Sandler, T. (1986): The theory of externalities, public goods, and club goods, Cambridge University Press, Cambridge, United States of America. 
Costa, L., Tekken, V., Kropp, J. (2009): Threat of sea level rise: Costs and benefits of adaptation in European coastal countries, in: Journal of Coastal Research, Special issue 56, 2009.

Cowen, T. (1988): The Theory of Market Failure - A critical examination, The Cato Institute, George Mason University Press, Fairfax, Virginia.

CWSS (2001): Coastal Protection and Sea Level Rise, Final Report, Common Wadden Sea Secretariat, Wilhelmshaven, Germany.

Dannenberg, A., Mennel, T., Osberghaus, D. and Sturm, B. (2009): The Economics of Adaptation to Climate Change - The Case of Germany, ZEW Discussion Paper 09-057, Centre for European Economic Research.

De Bruin, K.C., Dellink, R.B. (2009): How Harmful are Adaptation Restrictions, FEEM Nota di Lavoro 58.2009. Sustainable Development Series.

Ebi, K.L. (2008): Adaptation costs for climate change-related cases of diarrhoeal disease, malnutrition, and malaria in 2030, Globalization and Health, 4:9.

Eskeland, G.S., Mideksa, T.K. (2009): Climate Change and Residential Electricity Demand in Europe, Electronic copy available at: http://ssrn.com/abstract=1338835, downloaded on 18.12.2009.

European Council (1997): Resolution of the European Council on the Stability and Growth Pact, Amsterdam, 17 June 1997, Official Journal C 236, 02/08/1997 pp. 1-2.

Fankhauser, S. (1992): Global Warming Damage Costs: Some Monetary Estimates, CSERGE GEC Working Paper 92-29, University College London and University of East Anglia, Norwich.

Fankhauser, S. (1998): The Costs of Adapting to Climate Change, GEF Working Paper 16, Global Environment Facility.

Fankhauser, S., Smith, J.B., and Tol, R.S.J. (1999): Weathering climate change: some simple rules to guide adaptation decisions, Ecological Economics, Vol. 30, pp. 67-78.

Farber, D. (2009): Climate Adaptation and Federalism: Mapping the Issues, Electronic copy available at: http://ssrn.com/abstract=1468621, downloaded on 02.02.2010.

Fischer, G., Tubiello, F.N., van Velthuizen, H., Wiberg, D.A. (2007): Climate change impacts on irrigation water requirements: Effects of mitigation, 1990-2080, Technological Forecasting and Social Change 74 (2007) 1083-1107.

Hahn (2004): Künstliche Beschneiung im Alpenraum - Ein alpmedia-Hintergrundbericht, CIPRA-International. 
Heal, G., Kriström, B. (2002): Uncertainty and Climate Change, Environmental and Resource Economics 22, pp. 3-39.

Helm, D. (2002): Energy policy: security of supply, sustainability and competition, Energy Policy, 30(2002), 173-184.

HLUG - Hessisches Landesamt für Umwelt und Geologie (2005): Integriertes Klimaschutzprogramm Hessen, INKLIM 2012 Projektbaustein II: Klimawandel und Klimafolgen in Hessen, Abschlussbericht.

IMF (2008): The Fiscal Implications of Climate Change, Fiscal Affairs Department, International Monetary Fund, Electronic copy available at: https://www.imf.org/external/np/pp/eng/2008/022208.pdf, downloaded on 02.02.2010.

IPCC (2007): Climate Change 2007: Impacts, Adaptation and Vulnerability. Contribution of Working Group II to the Fourth Assessment Report of the Intergovernmental Panel on Climate Change [Parry, M.L., O.F. Canziani, J.P. Palutikof, P.J. van der Linden and C.E. Hanson, Eds.], Cambridge University Press, Cambridge, UK, 976 pp.

Jochem, E., Schade, W. (2009): Adaptation and Mitigation Strategies Supporting European Climate Policy, ADAM Deliverable D-M1.2, Fraunhofer Institute for Systems and Innovation Research, Munich.

Kemfert, C. (2007): Klimawandel kostet die Deutsche Volkswirtschaft Milliarden, DIW Wochenbericht 11/2007, 165-170.

Kirkinen, J., Martikainen, A., Holttinen, H., Savolainen, I., Auvinen, O. and Syri, S. (2005): Impacts on the energy sector and adaptation of the electricity network business under a changing climate in Finland. FINADAPT Working Paper 10, Finnish Environment Institute Mimeographs 340, Helsinki, 36 pp.

Liebermann, N., Zimmermann, C. (2000): Technik des Küstenschutzes (Teilprojekt), im Projekt: Klimaänderung und Unterweserregion (KLIMU) - Fallstudie Weserästuar des Bund-Länderprogramms Klimaänderung und Küste, Abschlussbericht, Franzius-Institut für Wasserbau und Küsteningenieurwesen.

Mai, S., Elsner, A., Meyer, V., Zimmermann, C. (2004): Klimawandel und präventives Risiko- und Küstenschutzmanagement an der deutschen Nordseeküste (KRIM): (Teilprojekt 2 - Klimaänderung und Küstenschutz), Endbericht, Universität Hannover, Franzius-Institut für Wasserbau und Küsteningenieurwesen.

Mankiw, N.G. (2003): Makroökonomik, 5th edition, Schäffer-Poeschel, Stuttgart.

Matsusaka, J.G. (1995): Fiscal Effects of the Voter Initiative: Evidence from the Last 30 Years, Journal of Political Economy, Vol. 103, No. 3, pp. 587-623. 
Mendelsohn, R. (2000), Efficient Adaptation to Climate Change, Climatic Change 45(3-4), pp. 583-600.

Ministry for Infrastructure and Transport (2009): Safeguarding of Venice and its Lagoons, www.salve.it, downloaded on 10.12.2009.

OECD (2008): Economic Aspects of Adaptation to Climate Change - Costs, Benefits and Policy Instruments, edited by S. Agrawala and S. Fankhauser.

Parry, M.; Arnell, N.; Berry, P.; Dodman, D.; Fankhauser, S.; Hope, C.; Kovats, S.; Nicholls, R.; Satterthwaite, D.; Tiffin, R.; Wheeler, T. (2009): Assessing the Costs of Adaptation to Climate Change: A Review of the UNFCCC and Other Recent Estimates, International Institute for Environment and Development and Grantham Institute for Climate Change, London.

Patt, A.G.; van Vuuren, D.P.; Berkhout, F.; Aaheim, A.; Hof, A.F.; Isaac, M. and Mechler, R. (2009): Adaptation in integrated assessment modeling: where do we stand?, Climatic Change.

Perrels, A., Rajala, R. and Honkatukia, J. (2005): Appraising the socio-economic impacts of climate change for Finland. FINADAPT Working Paper 12, Finnish Environment Institute Mimeographs 342, Helsinki, 30 pp.

Policy Research Corporation, PRC (2009): The economics of climate change adaptation in EU coastal areas, Final Report for the European Commission.

Pindyck, R. S., Rubinfeld, D. L. (1998): Microeconomics, 4th ed., Englewood Cliffs, NJ: Prentice Hall International Inc.

Samuelson, P. (1954): The Pure Theory of Public Expenditure, Review of Economics and Statistics, 36(4), 387-389.

Silander, J., Vehviläinen, B., Niemi, J, Arosilta, A., Dubrovin, T., Jormola, J., Keskisarja, V., Keto, A., Lepistö, A., Mäkinen, R, Ollila, M., Pajula, H., Pitkänen, H., Sammalkorpi, I., Suomalainen, M. and Veijalainen, N. (2006): Climate change adaptation for hydrology and water resources. FINADAPT Working Paper 6, Finnish Environment Institute Mimeographs 336, Helsinki, 52 pp.

Sioshansi, F.P., Pfaffenberger, W. (editors) (2006): Electricity Market Reform: An International Perspective, Elsevier, Oxford, 656 pp.Storesletten, K. (2000): Sustaining Fiscal Policy through Immigration, Journal of Political Economy, Vol. 108, No. 2, pp. 300-323.

Smith, J.B., Vogel, J.M. and Cromwell III, J.E. (2009): An architecture for government action on adaptation to climate change - An editorial comment, Climatic Change 95, 53-61. 
Swaroop, V., Jhaa, S., Rajkumarb, A.S. (2000): Fiscal effects of foreign aid in a federal system of governance: The case of India Journal of Public Economics, Volume 77, Issue 3, pp. 307-330.

Tol, R.S.J., Dowlatabadi, H. (2001): Vector-borne diseases, development \& climate change, Integrated Assessment 2, 173-181.

Tol, R.S.J. (2002a): Estimates of the Damage Costs of Climate Change Part I: Benchmark Estimates, Environmental and Resource Economics 21, 47-73.

Tol, R.S.J. (2002b): Estimates of the Damage Costs of Climate Change Part II: Dynamic Estimates, Environmental and Resource Economics 21, 135-160.

Tol, R.S.J. (2005): Adaptation and mitigation: trade-offs in substance and methods, Environmental Science \& Policy 8, 572-578.

UNFCCC (2007): Investment and Financial Flows to Address Climate Change. Climate Change Secretariat, Bonn.

United Nations, General Assembly (1966): International Covenant on Economic, Social and Cultural Rights, resolution 2200A (XXI), Electronic copy available at: http://www2.ohchr.org/english/law/pdf/cescr.pdf, downloaded on 15.03.2010.

Wolswijk, G. (2005): On some fiscal effects on mortgage debt growth in the EU, Working Paper Series, No. 526, European Central Bank.

World Bank (2009): The Costs to Developing Countries of Adapting to Climate Change New Methods and Estimates, The Global Report of the Economics of Adaptation to Climate Change Study, Consultation Draft. 


\section{A APPENDIX}

\section{A.1 Matrix}

Please see next page. 
Table 1: Adaptation costs in Germany summarised from the literature, normalised to annual costs in $€$ in prices of 2005.

\begin{tabular}{|c|c|c|c|c|c|c|c|}
\hline \multirow{2}{*}{ Scenario } & \multirow{2}{*}{$\begin{array}{c}\text { Methodology / } \\
\text { Model }\end{array}$} & \multirow{2}{*}{ Year } & \multirow{2}{*}{ Entries } & Agriculture & $\begin{array}{l}\text { Water } \\
\text { supply }\end{array}$ & $\begin{array}{l}\text { Inland } \\
\text { floods }\end{array}$ & $\begin{array}{l}\text { Coastal } \\
\text { floods }\end{array}$ \\
\hline & & & & $\begin{array}{c}\text { million } \\
2005 € \text { p.a. }\end{array}$ & $\begin{array}{c}\text { million } \\
2005 € \text { p.a. }\end{array}$ & $\begin{array}{c}\text { million } \\
2005 € \text { p.a. }\end{array}$ & $\begin{array}{c}\text { million } \\
2005 € \text { p.a. }\end{array}$ \\
\hline \multirow[t]{2}{*}{ past data } & \multirow[t]{2}{*}{$\begin{array}{c}\text { Econometric } \\
\text { study of past data }\end{array}$} & \multirow[t]{2}{*}{ 1985-2007 } & Costs & & & & \\
\hline & & & Source & & & & \\
\hline \multirow[t]{2}{*}{ past data } & \multirow{2}{*}{$\begin{array}{l}\text { Review of past } \\
\text { expenditure }\end{array}$} & \multirow[t]{2}{*}{ 2008-2009 } & Costs & & & & \\
\hline & & & Source & & & & \\
\hline \multirow{2}{*}{$\begin{array}{l}\text { SLR: } 15-50 \\
\text { cm by } \\
2100 ; \\
\text { Protection } \\
\text { level: } 1: 100 \\
\text { to } 1: 400 \\
\end{array}$} & \multirow{2}{*}{$\begin{array}{l}\text { Review of } \\
\text { scheduled } \\
\text { expenditure }\end{array}$} & \multirow{2}{*}{ 1998-2015 } & Costs & & & & $\begin{array}{l}143 \text { (not only due } \\
\text { to climate change) }\end{array}$ \\
\hline & & & Source & & & & $\begin{array}{l}\text { Policy Research } \\
\text { Corporation } 2009\end{array}$ \\
\hline \multirow{4}{*}{$\begin{array}{l}\text { SLR: } 70 \\
\text { cm, } \\
\text { maintain } \\
\text { current } \\
\text { protection } \\
\text { level }\end{array}$} & \multirow[t]{2}{*}{ Case study } & \multirow{2}{*}{ n.a. } & Costs & & & & $\begin{array}{l}46 \text { (one-time } \\
\text { investment, only } \\
\text { Lower Weser river) }\end{array}$ \\
\hline & & & Source & & & & $\begin{array}{l}\text { Liebermann and } \\
\text { Zimmermann } 2000\end{array}$ \\
\hline & \multirow[t]{2}{*}{ Case study } & \multirow[t]{2}{*}{ n.a. } & Costs & & & & $\begin{array}{l}31 \text { (one-time } \\
\text { investment, only } 4 \\
\text { focus points at the } \\
\text { North Sea, total } \\
\text { dike length } 85.2 \\
\text { km) }\end{array}$ \\
\hline & & & Source & & & & Mai et al. 2004 \\
\hline \multirow{2}{*}{$\begin{array}{l}\text { SLR: } 1 \mathrm{~m} \\
\text { by } 2100\end{array}$} & \multirow{2}{*}{$\begin{array}{l}\text { Case study, } \\
\text { expert opinion }\end{array}$} & \multirow{2}{*}{2050} & Costs & & & & 23 \\
\hline & & & Source & & & & Bräuer et al. 2009 \\
\hline \multirow{2}{*}{$\begin{array}{l}\text { SLR: } 1 \mathrm{~m} \\
\text { by } 2100\end{array}$} & \multirow{2}{*}{$\begin{array}{l}\text { Case study, } \\
\text { expert opinion }\end{array}$} & \multirow{2}{*}{2100} & Costs & & & & 91 \\
\hline & & & Source & & & & Bräuer et al. 2009 \\
\hline \multirow{2}{*}{$\begin{array}{l}\text { SLR: } 50 \mathrm{~cm} \\
\text { by } 2050\end{array}$} & \multirow[t]{2}{*}{ Case study } & \multirow[t]{2}{*}{2050} & Costs & & & & $\begin{array}{l}+75 \% \text { (only } \\
\text { Wadden Sea) }\end{array}$ \\
\hline & & & Source & & & & CWSS 2001 \\
\hline \multirow{2}{*}{ n.a. } & \multirow{2}{*}{$\begin{array}{l}\text { Case study, } \\
\text { rough estimates }\end{array}$} & \multirow{2}{*}{$2050-2100$} & Costs & & $37-711$ & & \\
\hline & & & Source & & Bräuer et al. 2009 & & \\
\hline A2 & $\begin{array}{c}\text { Forecast of } \\
\text { heating degree }\end{array}$ & 2100 & Costs & & & & \\
\hline & days, estimates & & Source & & & & \\
\hline B2 & Case study & 2050 & Costs & $\begin{array}{l}1.2-7.5 \text { (only fruit } \\
\text { sector in Hesse) }\end{array}$ & & & \\
\hline & & & Source & HLUG 2005 & & & \\
\hline $\mathrm{T}: 4,5^{\circ} \mathrm{C}$ by & WIAGFM Model & 2050 & Costs & 116 & & & \\
\hline 2100 & & & Source & Kemfert 2007 & & & \\
\hline $\mathrm{T}: 4,5^{\circ} \mathrm{C}$ by & WIAGFM Model & 2100 & Costs & 480 & & & \\
\hline 2100 & & & Source & Kemfert 2007 & & & \\
\hline & & & Costs & & & & 17.3 \\
\hline $\begin{array}{l}\text { A2, SLR: } \\
\text { relatively } \\
50-100 \mathrm{~cm} \\
\text { by } 2100, \\
\text { protection } \\
\text { level: } 100 \\
\text { years event }\end{array}$ & DIVA Model & $2000-2100$ & Source & & & & Costa et al. 2009 \\
\hline
\end{tabular}




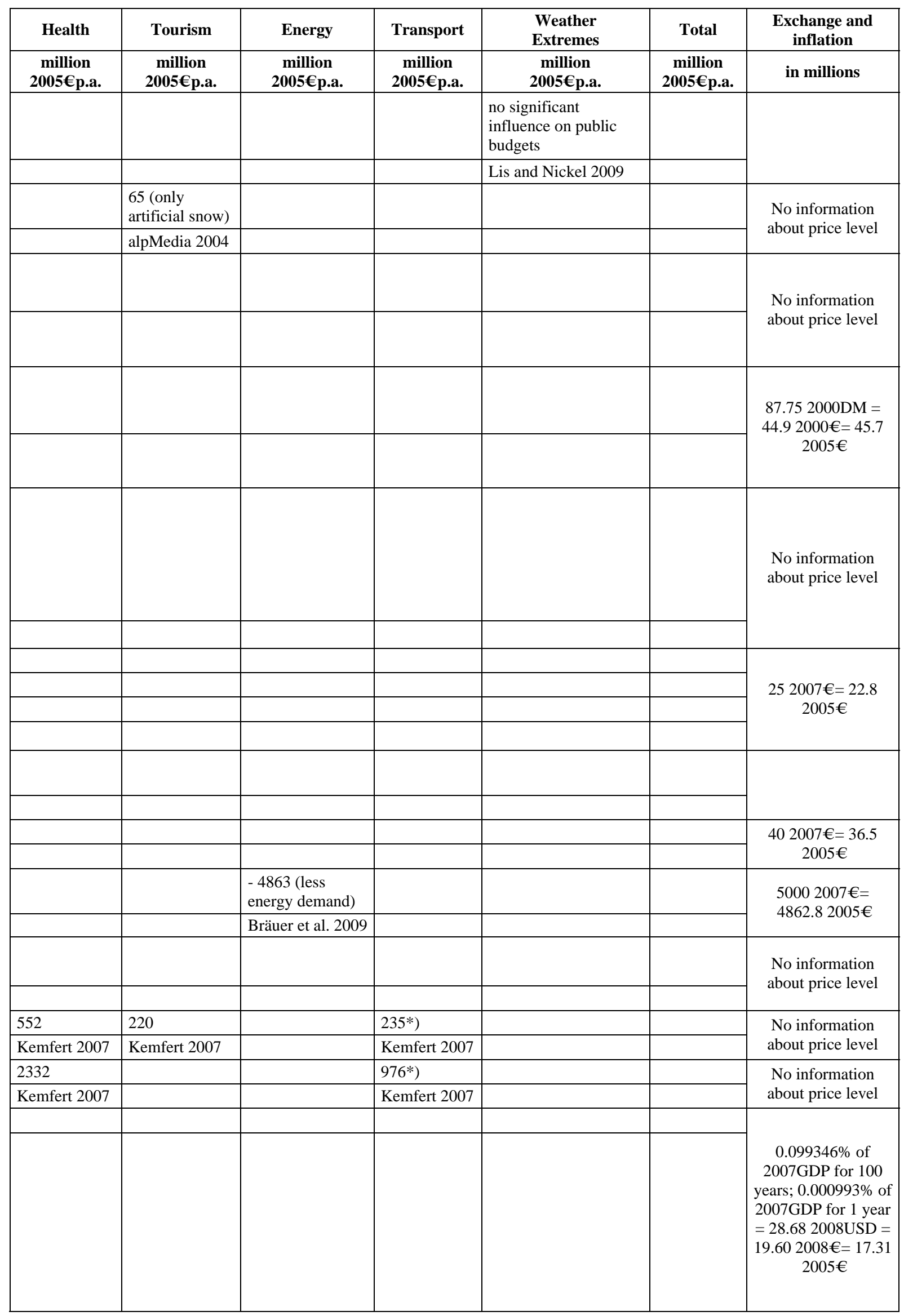


Table 2: Adaptation costs in Finland summarised from the literature, normalised to annual costs in $€$ in prices of 2005.

\begin{tabular}{|c|c|c|c|c|c|c|c|}
\hline \multirow{2}{*}{ Scenario } & \multirow{2}{*}{$\begin{array}{l}\text { Methodology / } \\
\text { Model }\end{array}$} & \multirow{2}{*}{ Year } & \multirow{2}{*}{ Entries } & Agriculture & $\begin{array}{l}\text { Water } \\
\text { supply }\end{array}$ & $\begin{array}{l}\text { Inland } \\
\text { floods }\end{array}$ & $\begin{array}{c}\text { Coastal } \\
\text { floods }\end{array}$ \\
\hline & & & & $\begin{array}{c}\text { million } \\
2005 € \text { p.a. }\end{array}$ & $\begin{array}{c}\text { million } \\
2005 € \text { p.a. }\end{array}$ & $\begin{array}{c}\text { million } \\
2005 € \text { p.a. }\end{array}$ & $\begin{array}{c}\text { million } \\
2005 € \text { p.a. }\end{array}$ \\
\hline \multirow[t]{2}{*}{ past data } & \multirow[t]{2}{*}{$\begin{array}{l}\text { Econometric study } \\
\text { of past data }\end{array}$} & \multirow[t]{2}{*}{$1985-2007$} & Costs & & & & \\
\hline & & & Source & & & & \\
\hline \multirow{2}{*}{$\mathrm{A} 1 \mathrm{~T}$} & \multirow{2}{*}{$\begin{array}{l}\text { Estimates based on } \\
\text { literature review }\end{array}$} & \multirow{2}{*}{2020} & Costs & & & \multicolumn{2}{|c|}{$<11$} \\
\hline & & & Source & & & \multicolumn{2}{|c|}{ Perrels et al. 2005} \\
\hline \multirow{2}{*}{$\mathrm{A} 1 \mathrm{~T}$} & \multirow{2}{*}{$\begin{array}{l}\text { Estimates based on } \\
\text { literature review }\end{array}$} & \multirow{2}{*}{2050} & Costs & & & \multicolumn{2}{|c|}{$<11$} \\
\hline & & & Source & & & \multicolumn{2}{|c|}{ Perrels et al. 2005} \\
\hline \multirow{2}{*}{$\mathrm{A} 1 \mathrm{~T}$} & \multirow{2}{*}{$\begin{array}{l}\text { Estimates based on } \\
\text { literature review }\end{array}$} & \multirow{2}{*}{2080} & Costs & & & \multicolumn{2}{|c|}{$<11$} \\
\hline & & & Source & & & \multicolumn{2}{|c|}{ Perrels et al. 2005} \\
\hline \multirow[t]{2}{*}{$\begin{array}{l}\text { Larger } \\
\text { future } \\
\text { floods }\end{array}$} & \multirow[t]{2}{*}{$\begin{array}{l}\text { Estimates based on } \\
\text { literature review }\end{array}$} & \multirow[t]{2}{*}{2070} & Costs & & & $\begin{array}{l}0.005-7 \text { (initial } \\
\text { investment) }\end{array}$ & $\begin{array}{l}\text { 1-10 (initial } \\
\text { investment, only } \\
\text { Pori) }\end{array}$ \\
\hline & & & Source & & & Silander et al. 2006 & Silander et al. 2006 \\
\hline \multirow{2}{*}{$\begin{array}{c}\text { SLR: } 60 \\
\text { cm, } \\
\text { maintain } \\
\text { current } \\
\text { protection } \\
\text { level }\end{array}$} & \multirow[b]{2}{*}{$\begin{array}{l}\text { Review of } \\
\text { scheduled } \\
\text { expenditure }\end{array}$} & \multirow[b]{2}{*}{ 1998-2015 } & Costs & & & & 0.45 \\
\hline & & & Source & & & & \begin{tabular}{|l} 
Policy Research \\
Corporation 2009
\end{tabular} \\
\hline \multirow[t]{2}{*}{ n.a. } & \multirow{2}{*}{$\begin{array}{l}\text { Simulation, } \\
\text { Estimates based on } \\
\text { literature review }\end{array}$} & \multirow[t]{2}{*}{2030} & Costs & & & & \\
\hline & & & Source & & & & \\
\hline \multirow[t]{2}{*}{ A1B } & \multirow{2}{*}{$\begin{array}{l}\text { Simulation, } \\
\text { Estimates based on } \\
\text { literature review }\end{array}$} & \multirow[t]{2}{*}{2100} & Costs & & & & \\
\hline & & & Source & & & & \\
\hline \multirow[b]{2}{*}{$\begin{array}{l}\text { A2, SLR: } \\
\text { relatively } \\
50-100 \mathrm{~cm} \\
\text { by } 2100, \\
\text { protection } \\
\text { level: } 100 \\
\text { years event }\end{array}$} & & & Costs & & & & 5.15 \\
\hline & DIVA Model & $2000-2100$ & Source & & & & Costa et al. 2009 \\
\hline
\end{tabular}




\begin{tabular}{|c|c|c|c|c|c|c|}
\hline Health & Tourism & Energy & Transport & $\begin{array}{l}\text { Weather } \\
\text { Extremes }\end{array}$ & Total & $\begin{array}{c}\text { Exchange and } \\
\text { inflation }\end{array}$ \\
\hline \multirow[t]{19}{*}{$\begin{array}{c}\text { million } \\
2005 € \text { p.a. }\end{array}$} & $\begin{array}{c}\text { million } \\
2005 € \text { p.a. }\end{array}$ & $\begin{array}{c}\text { million } \\
2005 € \text { p.a. }\end{array}$ & $\begin{array}{c}\text { million } \\
2005 € \text { p.a. }\end{array}$ & $\begin{array}{l}\text { million } \\
2005 € \text { p.a. }\end{array}$ & $\begin{array}{c}\text { million } \\
2005 € \text { p.a. }\end{array}$ & in millions \\
\hline & & & & $\begin{array}{l}\text { no significant } \\
\text { influence on public } \\
\text { budgets }\end{array}$ & & \\
\hline & & & & Lis and Nickel 2009 & & \\
\hline & & 1.1 (only maintenance) & & & & \multirow{6}{*}{$\begin{array}{c}12000 €=1.093 \\
2005 €\end{array}$} \\
\hline & & Perrels et al. 2005 & & & & \\
\hline & & 1.1 (only maintenance) & & & & \\
\hline & & Perrels et al. 2005 & & & & \\
\hline & & 1.1 (only maintenance) & & & & \\
\hline & & Perrels et al. 2005 & & & & \\
\hline & & & & & & \multirow[t]{2}{*}{$\begin{array}{l}\text { No information } \\
\text { about price level }\end{array}$} \\
\hline & & & & & & \\
\hline & & & & & & \multirow[b]{2}{*}{$\begin{array}{l}\text { No information } \\
\text { about price level }\end{array}$} \\
\hline & & & & & & \\
\hline & & $\begin{array}{l}-2 \% \text { (less energy } \\
\text { demand) }\end{array}$ & $\begin{array}{l}\text { 10-20 (buildings } \\
\text { and transport } \\
\text { infrastructure) }\end{array}$ & & & \multirow[t]{2}{*}{$\begin{array}{l}\text { No information } \\
\text { about price level }\end{array}$} \\
\hline & & Kirkinen et al. 2005 & Carter et al. 2007 & & & \\
\hline & & $\begin{array}{l}-4.5 \% \text { (less residential } \\
\text { electricity demand) }\end{array}$ & $\begin{array}{l}\text { >20 (buildings } \\
\text { and transport } \\
\text { infrastructure) }\end{array}$ & & & \multirow{2}{*}{$\begin{array}{l}\text { No information } \\
\text { about price level }\end{array}$} \\
\hline & & $\begin{array}{l}\text { Eskeland and Mideksa } \\
2009\end{array}$ & Carter et al. 2007 & & & \\
\hline & & & & & & \multirow[b]{2}{*}{$\begin{array}{c}0.422518 \% \text { of } \\
\text { 2007GDP for } 100 \\
\text { years; } \\
0.00422518 \% \text { of } \\
2007 \mathrm{GDP} \text { for } 1 \\
\text { year }=8.13 \\
2008 \mathrm{USD}=5.55 \\
2008 €=5.15 \\
2005 €\end{array}$} \\
\hline & & & & & & \\
\hline
\end{tabular}


Table 3: Adaptation costs in Italy summarised from the literature, normalised to annual costs in $€$ in prices of 2005.

\begin{tabular}{|c|c|c|c|c|c|c|c|}
\hline \multirow{2}{*}{ Scenario } & \multirow{2}{*}{$\begin{array}{c}\text { Methodology / } \\
\text { Model }\end{array}$} & \multirow{2}{*}{ Year } & \multirow{2}{*}{ Entries } & Agriculture & $\begin{array}{l}\text { Water } \\
\text { supply }\end{array}$ & $\begin{array}{l}\text { Inland } \\
\text { floods }\end{array}$ & $\begin{array}{c}\text { Coastal } \\
\text { floods }\end{array}$ \\
\hline & & & & $\begin{array}{c}\text { million } \\
2005 € \text { p.a. }\end{array}$ & $\begin{array}{c}\text { million } \\
2005 € \text { p.a. }\end{array}$ & \begin{tabular}{|c|} 
million \\
2005€ p.a.
\end{tabular} & $\begin{array}{c}\text { million } \\
2005 € \text { p.a. }\end{array}$ \\
\hline \multirow[b]{2}{*}{$\begin{array}{l}\text { VSL (Value of a } \\
\text { statistical Life) } \\
\text { median WTP } \\
\text { Risk Reduction } \\
\text { to die on health } \\
\text { effects of heat } \\
\text { waves }\end{array}$} & \multirow[b]{2}{*}{ survey } & \multirow[b]{2}{*}{2005} & Costs & & & & \\
\hline & & & Source & & & & \\
\hline \multirow[b]{2}{*}{$\begin{array}{l}\text { VSL (Value of a } \\
\text { statistical Life) } \\
\text { mean WTP } \\
\text { Risk Reduction } \\
\text { to die on health } \\
\text { effects of heat } \\
\text { waves }\end{array}$} & \multirow[b]{2}{*}{ survey } & \multirow[b]{2}{*}{2005} & Costs & & & & \\
\hline & & & Source & & & & \\
\hline \multirow[t]{2}{*}{ Discount rate 3.5} & \multirow[t]{2}{*}{ Case study } & \multirow[t]{2}{*}{2030} & Costs & & & & $\begin{array}{l}\text { 1.5-2.1 (in 2030) } \\
\text { only Venice but without } \\
\text { MOSE }\end{array}$ \\
\hline & & & Source & & & & $\begin{array}{l}\text { Carraro and Sgobbi } \\
2008 \\
\end{array}$ \\
\hline \multirow[t]{2}{*}{ n.a. } & \multirow[t]{2}{*}{$\begin{array}{l}\text { Review of } \\
\text { scheduled } \\
\text { expenditure }\end{array}$} & \multirow[t]{2}{*}{ 2009-2015 } & Costs & & & & $\begin{array}{l}790.8 \text { (in 2009-2011, } \\
\text { including MOSE } \\
\text { project) } \\
23.30 \text { (in 2012-2015, } \\
\text { MOSE project } \\
\text { completed) }\end{array}$ \\
\hline & & & Source & & & & $\begin{array}{l}\text { Policy Research } \\
\text { Corporation } 2009\end{array}$ \\
\hline \multirow{2}{*}{ n.a. } & \multirow{2}{*}{$\begin{array}{l}\text { expenditure } \\
\text { forecast for } \\
\text { MOSE project }\end{array}$} & \multirow{2}{*}{ n.a. } & Costs & & & & $\begin{array}{l}4680 \text { total for MOSE } \\
\text { project (no time } \\
\text { horizon) }\end{array}$ \\
\hline & & & Source & & & & $\begin{array}{l}\text { Ministry for } \\
\text { Infrastructure and } \\
\text { Transport } 2009\end{array}$ \\
\hline \multirow[b]{2}{*}{$\begin{array}{c}\text { A2, SLR: } \\
\text { relatively } 50-100 \\
\text { cm by } 2100, \\
\text { protection level: } \\
100 \text { years event }\end{array}$} & \multirow[b]{2}{*}{ DIVA Model } & \multirow[b]{2}{*}{$2000-2100$} & Costs & & & & 26.9 \\
\hline & & & Source & & & & Costa et al. 2009 \\
\hline
\end{tabular}




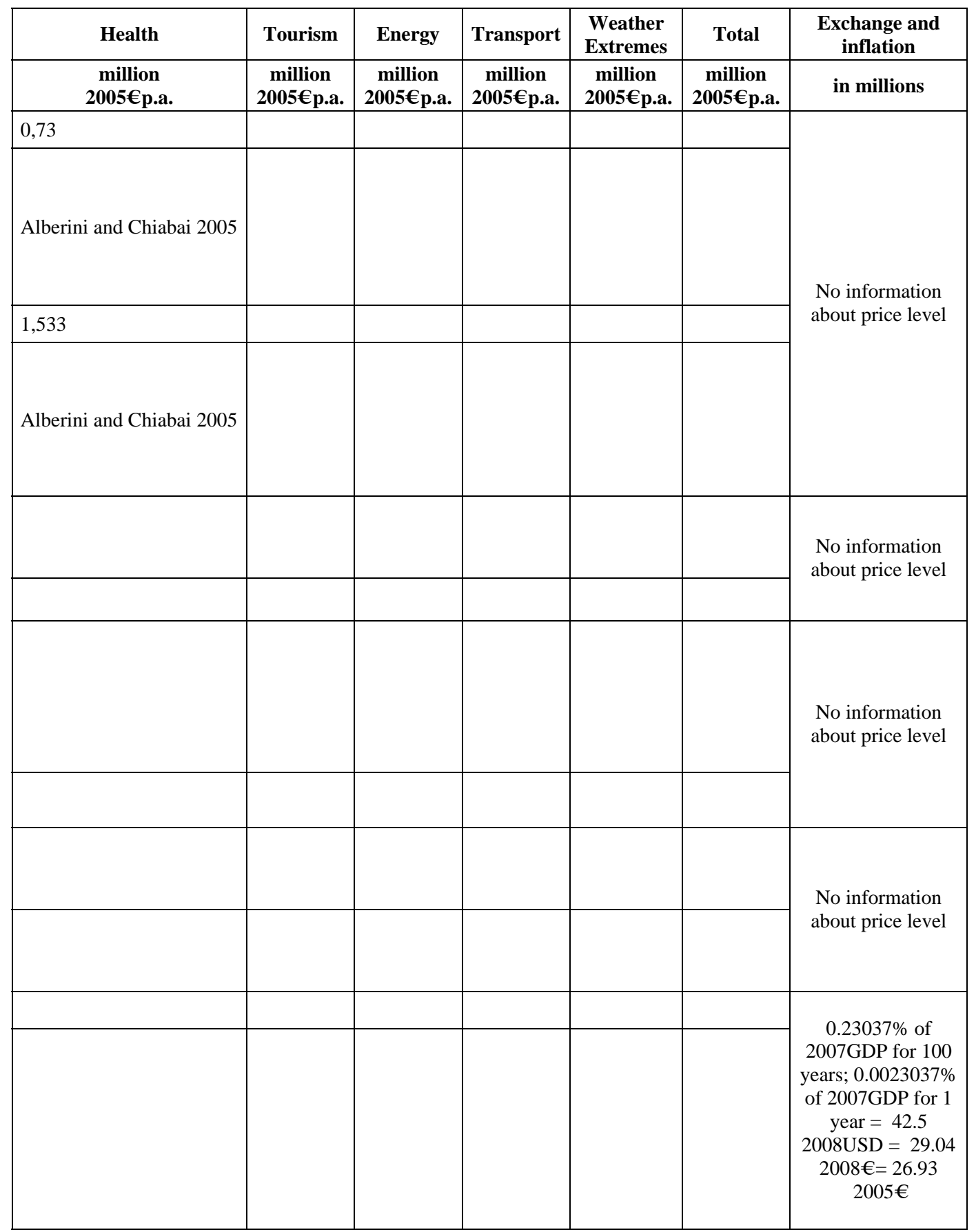


Table 4: Adaptation costs in Europe summarised from the literature, normalised to annual costs in $€$ in prices of 2005.

\begin{tabular}{|c|c|c|c|c|c|c|c|}
\hline \multirow{2}{*}{ Region } & \multirow{2}{*}{ Scenario } & \multirow{2}{*}{$\begin{array}{c}\text { Methodology / } \\
\text { Model }\end{array}$} & \multirow{2}{*}{ Year } & \multirow{2}{*}{ Entries } & Agriculture & $\begin{array}{l}\text { Water } \\
\text { supply }\end{array}$ & $\begin{array}{l}\text { Inland } \\
\text { floods }\end{array}$ \\
\hline & & & & & $\begin{array}{c}\text { million } \\
2005 € \text { p.a. }\end{array}$ & \begin{tabular}{|c|} 
million \\
$2005 €$ p.a. \\
\end{tabular} & $\begin{array}{c}\text { million } \\
2005 € \text { p.a }\end{array}$ \\
\hline \multirow[t]{2}{*}{ EU } & \multirow[t]{2}{*}{$\begin{array}{l}\text { SLR: } 25 \mathrm{~cm} \text {, } \\
\text { total } \\
\text { protection }\end{array}$} & \multirow[t]{2}{*}{$\begin{array}{l}\text { Global CGE, } 8 \\
\text { regions }\end{array}$} & \multirow[t]{2}{*}{2050} & Costs & & & \\
\hline & & & & Source & & & \\
\hline \multirow{6}{*}{ EU27 } & \multirow{3}{*}{$\begin{array}{c}\text { A2, SLR: } 88 \\
\text { cm by } 2100 \text {, } \\
\text { optimal } \\
\text { protection }\end{array}$} & & 2020-2029 & Costs & & & \\
\hline & & & 2080-2089 & Costs & & & \\
\hline & & & & Source & & & \\
\hline & \multirow{3}{*}{$\begin{array}{l}\text { B2, SLR: } 9 \\
\text { cm by } 2100 \text {, } \\
\text { optimal } \\
\text { protection }\end{array}$} & & 2020-2029 & Costs & & & \\
\hline & & & 2080-2089 & Costs & & & \\
\hline & & & & Source & & & \\
\hline \multirow{16}{*}{$\begin{array}{l}\text { Western } \\
\text { Europe }\end{array}$} & \multirow{4}{*}{$\begin{array}{l}\text { A2r } \\
\text { (population } \\
\text { growth } \\
\text { lower than } \\
\text { A2) }\end{array}$} & \multirow{8}{*}{$\begin{array}{l}\text { Climate model } \\
\text { Hadley, } \\
\text { agriculture } \\
\text { model AEZ- } \\
\text { BLS, cost } \\
\text { estimates }\end{array}$} & 2030 & Costs & 966 (only irrigation) & & \\
\hline & & & 2050 & Costs & 1544 (only irrigation) & & \\
\hline & & & 2080 & Costs & 2702 (only irrigation) & & \\
\hline & & & & Source & Fischer et al. 2007 & & \\
\hline & \multirow{4}{*}{ B1 } & & 2030 & Costs & 290 (only irrigation) & & \\
\hline & & & 2050 & Costs & 450 (only irrigation) & & \\
\hline & & & 2080 & Costs & 547 (only irrigation) & & \\
\hline & & & & Source & Fischer et al. 2007 & & \\
\hline & & \multirow{8}{*}{$\begin{array}{l}\text { Climate model } \\
\text { CSIRO, } \\
\text { agriculture } \\
\text { model AEZ- } \\
\text { BLS, cost } \\
\text { estimates }\end{array}$} & 2030 & Costs & 161 (only irrigation) & & \\
\hline & (population & & 2050 & Costs & 322 (only irrigation) & & \\
\hline & $\begin{array}{l}\text { growth } \\
\text { lower than }\end{array}$ & & 2080 & Costs & 611 (only irrigation) & & \\
\hline & & & & Source & Fischer et al. 2007 & & \\
\hline & \multirow{4}{*}{ B1 } & & 2030 & Costs & 225 (only irrigation) & & \\
\hline & & & 2050 & Costs & 290 (only irrigation) & & \\
\hline & & & 2080 & Costs & 386 (only irrigation) & & \\
\hline & & & & Source & Fischer et al. 2007 & & \\
\hline \multirow{2}{*}{$\begin{array}{l}\text { Western } \\
\text { Europe }\end{array}$} & \multirow{4}{*}{$\begin{array}{l}2 \mathrm{x} \mathrm{CO} 2, \mathrm{~T}= \\
2.5^{\circ} \mathrm{C}, \mathrm{SLR}: \\
\quad 44 \mathrm{~cm}\end{array}$} & \multirow{4}{*}{$\begin{array}{l}\text { AD-WITCH, } \\
\text { CGE ICES, cost } \\
\text { estimates }\end{array}$} & \multirow{4}{*}{ 2060-2065 } & Costs & 6274 (only irrigation) & 2655 & \\
\hline & & & & Source & $\begin{array}{l}\text { Bosello } \\
\text { et al. } 2009\end{array}$ & \begin{tabular}{|l|} 
Bosello \\
et al. 2009
\end{tabular} & \\
\hline \multirow{2}{*}{$\begin{array}{l}\text { Eastern } \\
\text { Europe }\end{array}$} & & & & Costs & 9894 (only irrigation) & 4263 & \\
\hline & & & & Source & $\begin{array}{l}\text { Bosello } \\
\text { et al. } 2009\end{array}$ & $\begin{array}{l}\text { Bosello } \\
\text { et al. } 2009\end{array}$ & \\
\hline \multirow[t]{2}{*}{ Europe } & \multirow{2}{*}{$\begin{array}{c}\text { AD-RICE } \\
\text { (emissions }< \\
\mathrm{B} 2, \mathrm{~T}=2^{\circ} \mathrm{C} \\
\text { by 2100) }\end{array}$} & \multirow{2}{*}{$\begin{array}{c}\text { Global CGE, } 13 \\
\text { regions, optimal } \\
\text { adaptation and } \\
\text { mitigation }\end{array}$} & \multirow[t]{2}{*}{ by 2155} & Costs & & & \\
\hline & & & & Source & & & \\
\hline
\end{tabular}




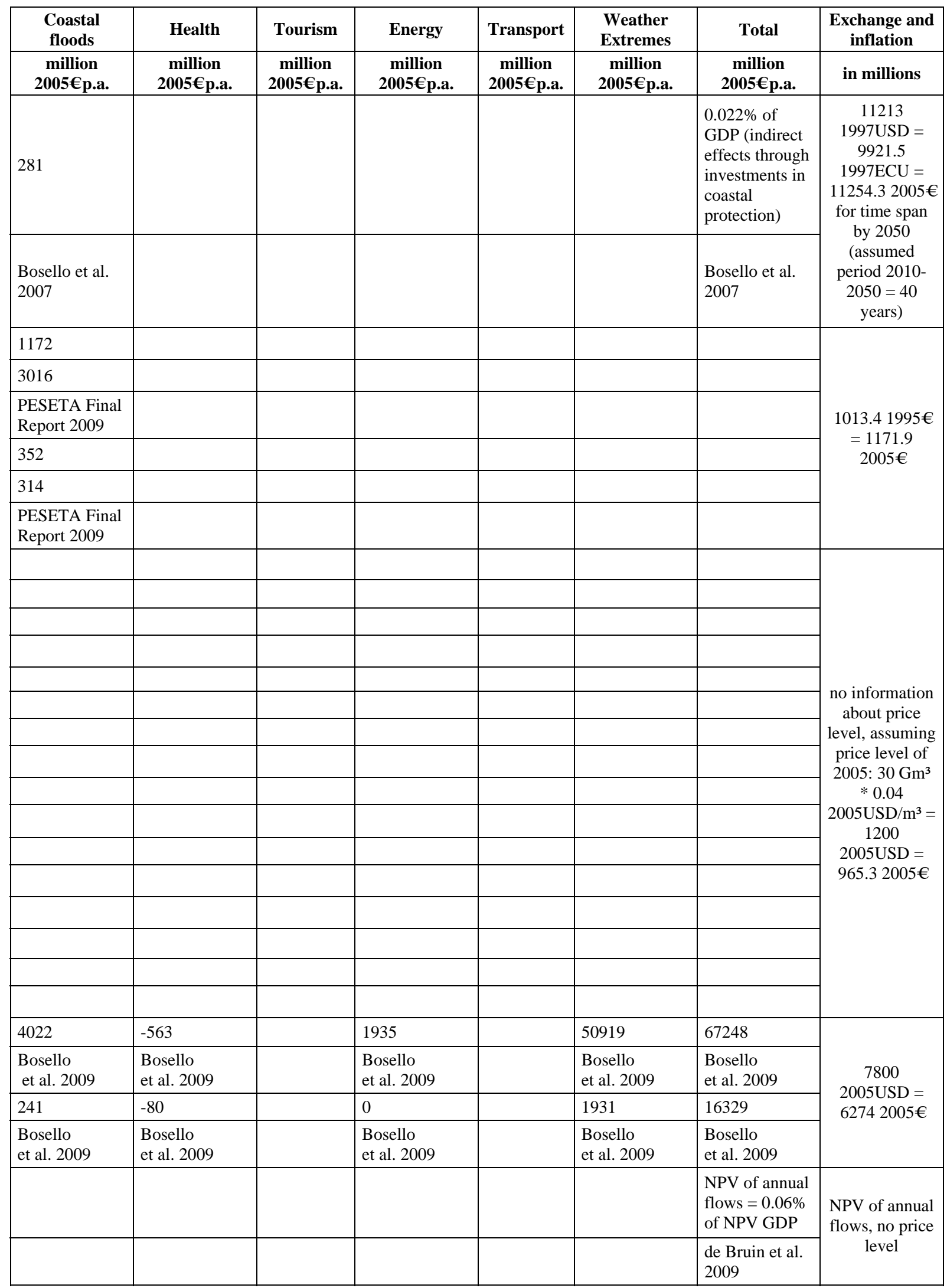




\begin{tabular}{|c|c|c|c|c|c|c|c|}
\hline \multirow{2}{*}{ Region } & \multirow{2}{*}{ Scenario } & \multirow{2}{*}{$\begin{array}{l}\text { Methodology / } \\
\text { Model }\end{array}$} & \multirow{2}{*}{ Year } & \multirow{2}{*}{ Entries } & Agriculture & $\begin{array}{l}\text { Water } \\
\text { supply }\end{array}$ & $\begin{array}{l}\text { Inland } \\
\text { floods }\end{array}$ \\
\hline & & & & & $\begin{array}{c}\text { million } \\
2005 € \text { p.a. }\end{array}$ & $\begin{array}{c}\text { million } \\
2005 € \text { p.a. }\end{array}$ & $\begin{array}{c}\text { million } \\
2005 € \text { p.a. }\end{array}$ \\
\hline \multirow{5}{*}{$\begin{array}{c}\text { EU27 + } \\
\text { Norway + } \\
\text { Switzerland }\end{array}$} & \multirow{5}{*}{$\begin{array}{c}4^{\circ} \mathrm{C} \\
\text { warming by } \\
2100\end{array}$} & \multirow{5}{*}{$\begin{array}{l}\text { Partial } \\
\text { Equilibrium } \\
\text { models }\end{array}$} & 2020 & Costs & & & \\
\hline & & & 2035 & Costs & & & \\
\hline & & & & & & & \\
\hline & & & 2050 & Costs & & & \\
\hline & & & & Source & & & \\
\hline \multirow{7}{*}{$\begin{array}{l}\text { OECD } \\
\text { Europe }\end{array}$} & \multirow{2}{*}{$\begin{array}{c}\text { A1B, SLR: } 9 \\
\text { cm by } 2030\end{array}$} & \multirow{2}{*}{$\begin{array}{c}\text { Estimates based } \\
\text { on literature } \\
\text { review }\end{array}$} & \multirow[b]{2}{*}{2030} & Costs & & 875 & \\
\hline & & & & Source & & $\begin{array}{l}\text { UNFCCC } \\
2007\end{array}$ & \\
\hline & \multirow[b]{2}{*}{$\begin{array}{l}\text { B1, SLR: } 9 \\
\text { cm by } 2030\end{array}$} & \multirow[b]{2}{*}{$\begin{array}{c}\text { Estimates based } \\
\text { on literature } \\
\text { review }\end{array}$} & \multirow[b]{2}{*}{2030} & Costs & & 251 & \\
\hline & & & & Source & & $\begin{array}{l}\text { UNFCCC } \\
2007\end{array}$ & \\
\hline & \multirow[b]{2}{*}{$\begin{array}{l}\text { SLR: } 1 \mathrm{~m} \text { by } \\
\quad 2100\end{array}$} & \multirow[b]{2}{*}{$\begin{array}{l}\text { Estimates based } \\
\text { on literature } \\
\text { review }\end{array}$} & \multirow[b]{2}{*}{$2000-2100$} & Costs & & & \\
\hline & & & & Source & & & \\
\hline & $\mathrm{T}: 1^{\circ} \mathrm{C}$ & $\begin{array}{c}\text { Estimates based } \\
\text { on literature } \\
\text { review }\end{array}$ & n.a. & Source & & & \\
\hline
\end{tabular}




\begin{tabular}{|c|c|c|c|c|c|c|c|}
\hline $\begin{array}{l}\text { Coastal } \\
\text { floods }\end{array}$ & Health & Tourism & Energy & Transport & $\begin{array}{l}\text { Weather } \\
\text { Extremes }\end{array}$ & Total & $\begin{array}{c}\begin{array}{c}\text { Exchange and } \\
\text { inflation }\end{array} \\
\end{array}$ \\
\hline $\begin{array}{l}\text { million } \\
2005 € \text { p.a. }\end{array}$ & $\begin{array}{l}\text { million } \\
2005 € \text { p.a. }\end{array}$ & $\begin{array}{c}\text { million } \\
2005 € \text { p.a. }\end{array}$ & $\begin{array}{l}\text { million } \\
2005 € \text { p.a. }\end{array}$ & $\begin{array}{c}\text { million } \\
2005 € \text { p.a. }\end{array}$ & $\begin{array}{c}\text { million } \\
2005 € \text { p.a. }\end{array}$ & \begin{tabular}{|c|} 
million \\
$2005 €$ p.a.
\end{tabular} & in millions \\
\hline & & & $\begin{array}{l}\text { - } 6941 \text { (less energy } \\
\text { demand) }+4300 \\
\text { (additional cooling } \\
\text { investments) }\end{array}$ & & & & \multirow{4}{*}{$\begin{array}{c}\text { No information } \\
\text { about price } \\
\text { level }\end{array}$} \\
\hline & & & $\begin{array}{l}\text { - } 15602 \text { (less energy } \\
\text { demand) + } 6200 \\
\text { (additional cooling } \\
\text { investments) }\end{array}$ & & & & \\
\hline & & & $\begin{array}{l}\text { - } 27663 \text { (less energy } \\
\text { demand) + } 8400 \\
\text { (additional cooling } \\
\text { investments) }+1000 \\
\text { (additional } \\
\text { investments in power } \\
\text { plant cooling } \\
\text { measures) }\end{array}$ & $\begin{array}{l}3000-6000 \\
\text { (only } \\
\text { infrastructure) }\end{array}$ & & & \\
\hline & & & $\begin{array}{l}\text { Jochem and Schade } \\
2009\end{array}$ & \begin{tabular}{|l|} 
Jochem and \\
Schade 2009 \\
\end{tabular} & & & \\
\hline 593 & & & & & $804-13715$ & & \multirow{4}{*}{$\begin{array}{c}87000 \\
\text { 2005USD for } \\
\text { investment by } \\
2030,25 \% \text { for } \\
\text { adaptation } \\
21750 \\
2005 \text { USD = } \\
174962005 € \\
\text { for time span, } \\
8752005 € \text { as } \\
\text { annual costs }\end{array}$} \\
\hline $\begin{array}{l}\text { UNFCCC } \\
2007\end{array}$ & & & & & $\begin{array}{l}\text { UNFCCC } \\
2007\end{array}$ & & \\
\hline 502 & & & & & $804-13715$ & & \\
\hline $\begin{array}{l}\text { UNFCCC } \\
2007\end{array}$ & & & & & $\begin{array}{l}\text { UNFCCC } \\
2007\end{array}$ & & \\
\hline \multicolumn{7}{|l|}{1612} & \multirow[b]{2}{*}{$\begin{array}{l}\text { No information } \\
\text { about price } \\
\text { level, assuming } \\
\text { price level of } \\
\text { 2000: } 136000 \\
\text { 2000USD = } \\
147516.5 \\
2000 €= \\
161238.3 \\
2005 € \text {, original } \\
\text { results for } \\
\text { period of } 100 \\
\text { years }\end{array}$} \\
\hline \multirow[t]{3}{*}{ Tol 2002} & & & & & & & \\
\hline & $\begin{array}{l}\text { no adaptation } \\
\text { costs for } \\
\text { diarrhea, } \\
\text { malnutrion } \\
\text { and malaria }\end{array}$ & & $\begin{array}{l}6350 \text { (additional } \\
\text { cooling demand, } \\
\text { saved heating } \\
\text { expenditure) }\end{array}$ & & & & \multirow{2}{*}{$\begin{array}{c}\text { No information } \\
\text { about price } \\
\text { level, assuming } \\
\text { price level of } \\
\text { 1995: 7100 } \\
\text { 1995USD = } \\
5451.4 \\
\text { 1995ECU = } \\
\text { 6350.2 2005€ }\end{array}$} \\
\hline & $\begin{array}{l}\text { Tol and } \\
\text { Dowlatabadi } \\
2001\end{array}$ & & Tol 2002 & & & & \\
\hline
\end{tabular}




\begin{tabular}{|c|c|c|c|c|c|c|c|}
\hline \multirow{2}{*}{ Region } & \multirow{2}{*}{ Scenario } & \multirow{2}{*}{$\begin{array}{c}\text { Methodology } \\
\text { / Model }\end{array}$} & \multirow{2}{*}{ Year } & \multirow{2}{*}{ Entries } & Agriculture & $\begin{array}{l}\text { Water } \\
\text { supply }\end{array}$ & $\begin{array}{l}\text { Inland } \\
\text { floods }\end{array}$ \\
\hline & & & & & $\begin{array}{c}\text { million } \\
2005 € \text { p.a. }\end{array}$ & $\begin{array}{c}\text { million } \\
2005 € \text { p.a. }\end{array}$ & $\begin{array}{c}\text { million } \\
2005 € \text { p.a. }\end{array}$ \\
\hline \multirow{19}{*}{$\begin{array}{l}\text { Eastern } \\
\text { Europe and } \\
\text { FSU }\end{array}$} & \multirow{5}{*}{$\begin{array}{l}\text { NCAR } \\
\text { (wet) }\end{array}$} & \multirow{19}{*}{$\begin{array}{c}\text { Estimates } \\
\text { based on } \\
\text { literature } \\
\text { review }\end{array}$} & 2010-2019 & Costs & & & \\
\hline & & & 2020-2029 & Costs & & & \\
\hline & & & 2030-2039 & Costs & & & \\
\hline & & & 2040-2049 & Costs & & & \\
\hline & & & & Source & & & \\
\hline & \multirow{5}{*}{$\begin{array}{l}\text { CSIRO } \\
\text { (dry) }\end{array}$} & & 2010-2019 & Costs & & & \\
\hline & & & 2020-2029 & Costs & & & \\
\hline & & & 2030-2039 & Costs & & & \\
\hline & & & 2040-2049 & Costs & & & \\
\hline & & & & Source & & & \\
\hline & \multirow{2}{*}{$\begin{array}{l}\text { NCAR } \\
\text { (wet) }\end{array}$} & & \multirow[t]{2}{*}{$2010-2050$} & Costs & $\begin{array}{l}80 \text { (research) } \\
80 \text { (irrigation) }\end{array}$ & $\begin{array}{l}80 \text { (only } \\
\text { infrastructure) } \\
+724\end{array}$ & 1125 \\
\hline & & & & Source & $\begin{array}{l}\text { World Bank } \\
2009\end{array}$ & World Bank 2009 & $\begin{array}{l}\text { World Bank } \\
2009\end{array}$ \\
\hline & \multirow{2}{*}{$\begin{array}{l}\text { CSIRO } \\
\text { (dry) }\end{array}$} & & \multirow{2}{*}{$2010-2050$} & Costs & $\begin{array}{l}80 \text { (research) } \\
80 \text { (irrigation) }\end{array}$ & -241 & 483 \\
\hline & & & & Source & $\begin{array}{l}\text { World Bank } \\
2009\end{array}$ & World Bank 2009 & $\begin{array}{l}\text { World Bank } \\
2009\end{array}$ \\
\hline & \multirow{5}{*}{$\begin{array}{l}\text { SLR: } 87,2 \\
\text { cm by } 2100\end{array}$} & & 2010-2019 & Costs & & & \\
\hline & & & 2020-2029 & Costs & & & \\
\hline & & & 2030-2039 & Costs & & & \\
\hline & & & 2040-2049 & Costs & & & \\
\hline & & & & Source & & & \\
\hline \multirow{2}{*}{$\begin{array}{l}\text { EC12 } \\
\text { without } \\
\text { GDR }\end{array}$} & \multirow{2}{*}{$\begin{array}{l}\text { SLR: } 50 \\
\text { cm and T: } \\
2,5^{\circ} \mathrm{C} \text { by } \\
2100\end{array}$} & \multirow{2}{*}{$\begin{array}{c}\text { Partial } \\
\text { Equilibrium }\end{array}$} & \multirow{2}{*}{$2000-2100$} & Costs & & & \\
\hline & & & & Source & & & \\
\hline \multirow[t]{2}{*}{$\begin{array}{c}\text { Western } \\
\text { Europe + } \\
\text { Croatia, } \\
\text { Cypros, } \\
\text { Slovenia }\end{array}$} & \multirow{2}{*}{$\begin{array}{c}\text { unmitigated } \\
\text { IPCC IS92a } \\
\text { scenario, } \\
\text { medium } \\
\text { estimate } \\
\end{array}$} & \multirow[t]{2}{*}{$\begin{array}{c}\text { Simulation, } \\
\text { Estimates } \\
\text { based on } \\
\text { literature } \\
\text { review }\end{array}$} & \multirow[t]{2}{*}{ up to 2030} & Costs & & & \\
\hline & & & & Source & & & \\
\hline
\end{tabular}




\begin{tabular}{|c|c|c|c|c|c|c|c|}
\hline $\begin{array}{c}\text { Coastal } \\
\text { floods }\end{array}$ & Health & Tourism & Energy & Transport & $\begin{array}{l}\text { Weather } \\
\text { Extremes }\end{array}$ & Total & \begin{tabular}{|c|}
$\begin{array}{c}\text { Exchange and } \\
\text { inflation }\end{array}$ \\
\end{tabular} \\
\hline \multirow[t]{13}{*}{$\begin{array}{c}\text { million } \\
2005 € \text { p.a. }\end{array}$} & $\begin{array}{c}\text { million } \\
2005 € \text { p.a. }\end{array}$ & $\begin{array}{c}\text { million } \\
2005 € \text { p.a. }\end{array}$ & $\begin{array}{c}\text { million } \\
2005 € \text { p.a. }\end{array}$ & $\begin{array}{c}\text { million } \\
2005 € \text { p.a. }\end{array}$ & $\begin{array}{c}\text { million } \\
2005 € \text { p.a. }\end{array}$ & $\begin{array}{c}\text { million } \\
2005 € \text { p.a. }\end{array}$ & in millions \\
\hline & & & & & 1210 & & \multirow{17}{*}{$\begin{array}{l}1 \text { 2005USD = } \\
0.80442005 €\end{array}$} \\
\hline & & & & & 1530 & & \\
\hline & & & & & 3540 & & \\
\hline & & & & & 4260 & & \\
\hline & & & & & $\begin{array}{l}\text { World Bank } \\
2009\end{array}$ & & \\
\hline & & & & & 563 & & \\
\hline & & & & & 885 & & \\
\hline & & & & & 1210 & & \\
\hline & & & & & 1690 & & \\
\hline & & & & & $\begin{array}{l}\text { World Bank } \\
2009\end{array}$ & & \\
\hline & $\begin{array}{l}563 \text { (only } \\
\text { infrastructure) }\end{array}$ & & $\begin{array}{l}483 \text { (only } \\
\text { infrastructure) }\end{array}$ & $\begin{array}{l}804 \text { (only } \\
\text { infrastructure) }\end{array}$ & & & \\
\hline & $\begin{array}{l}\text { World Bank } \\
2009\end{array}$ & & $\begin{array}{l}\text { World Bank } \\
2009\end{array}$ & $\begin{array}{l}\text { World Bank } \\
2009\end{array}$ & & & \\
\hline \multicolumn{7}{|l|}{1930} & \\
\hline \multicolumn{7}{|l|}{2090} & \\
\hline \multicolumn{7}{|l|}{2250} & \\
\hline \multicolumn{7}{|l|}{2490} & \\
\hline \multicolumn{7}{|l|}{$\begin{array}{l}\text { World } \\
\text { Bank } 2009 \\
\end{array}$} & \\
\hline 140 & & & $\begin{array}{l}7014 \text { (only } \\
\text { additional } \\
\text { electricity } \\
\text { expenditures) }\end{array}$ & & & & \multirow{2}{*}{$\begin{array}{c}\text { No information } \\
\text { about price } \\
\text { level, assuming } \\
\text { price level = } \\
\text { 1990: } 140 \\
\text { 1990USD = } \\
\text { 110 1990ECU } \\
=1402005 €\end{array}$} \\
\hline \multirow[t]{3}{*}{$\begin{array}{l}\text { Fankhauser } \\
1992\end{array}$} & & & $\begin{array}{l}\text { Fankhauser } \\
1992\end{array}$ & & & & \\
\hline & $\begin{array}{l}\text { no adaptation } \\
\text { costs for } \\
\text { diarrhea, } \\
\text { malnutrion and } \\
\text { malaria }\end{array}$ & & & & & & \\
\hline & Ebi 2007 & & & & & & \\
\hline
\end{tabular}




\section{A.2 Description of the Matrix}

\section{A.2.1 Regional coverage}

The first column of the matrix indicates the region for which the costs are estimated. Note that for European adaptation costs some studies refer to total Europe, some to the EU in a specific composition and others to the European OECD countries. Particularly problematic are the figures for Eastern Europe and the Former Soviet Union, as only a small and unknown part of these figures are attributable to current EU member states. Interpreting the entries of the matrix, this has to be kept in mind.

\section{A.2.2 Scenarios}

In the second column, the climate scenarios and socio-economic scenarios which form the basis for any calculation or estimation are named. This information is particularly important to classify the subsequent results and to get an insight whether they are rather optimistic or pessimistic. Moreover, in studies with identical regional covering and scenarios, time spans and methodologies can be compared. Unfortunately, the inadequate data provides us with hardly more than one comparable country-specific study. Nevertheless, as knowledge about adaptation costs is evolving, there may be the opportunity to gradually fill the numerous gaps in the matrix. This is possible only under the condition that the development of climate science does not lead to significantly new scenarios, because then again results would lose their direct comparability.

Beside the scenarios regarding climate and socio-economic developments, adaptation scenarios are of great relevance. For example, there is a fundamental difference between the assumption of "total protection" of the current shoreline (i.e. protecting the land from every possible storm surge) and the assumption of "optimal coastal protection”, which would incorporate the costs of protection into the decision. In the latter case abandoning highly endangered areas will be the consequence and the total costs will be lower than in the former case. In the real world, there is often a policy of determining a certain protection level, since the realisation of optimal protection is not always practicable due to lack of relevant data. A protection level of, say 1:400 means that the protection structures are designed to resist an event which statistically occurs every 400 years only. By setting these lump-sum protection levels the policy-makers avoid extensive cost-benefit-calculations for each coastal site. For the magnitude of adaptation costs, these adaptation decisions are of course crucial and every policy change significantly changes the involved costs. 


\section{A.2.3 Time coverage and annualisation}

Sometimes the cost estimates are calculated for only one point in time in the future, e.g. 2050, and sometimes they are estimated for a series of consecutive years, e.g. the annual value will occur every year between 2020 and 2030. Hence, the year (respectively period) is indicated in the fourth column. By comparing estimates from similar studies with different time horizons, one can find an increase in expected adaptation costs over time. This is not surprising as climate damages increase over time, which also induces higher adaptation needs.

Few sources give detailed information on annual costs for a given time period. One of them is Policy Research Corporation (2009), which names the scheduled expenditures for coastal protection by reviewing national and regional master plans up to 2015. In these cases we only give the average annual costs. As long as the annual amounts do not differ considerably, this is reasonable - in the other cases we have indicated the exact annual costs.

For reasons of comparability we derived the annual costs if costs were given for a time period longer than one year. That is, numbers calculated for a period of $\mathrm{N}$ years were divided by $\mathrm{N}$ to receive the annual costs. This implies basically two simplifying assumptions: Firstly, adaptation costs are assumed to be constant over time. In reality, adaptation costs may increase over time (see above); but as no information about the exact distribution is given we choose the equal distribution. Secondly, we ignore inflation. The presented data are in prices of 2005 and therefore do not reflect price changes over time. The simple division by $\mathrm{N}$ does not, however, assume a discount rate of zero. The matrix just gives the estimated adaptation costs which may occur at a future point of time. We do not calculate these future costs in present values - only in this case discounting would become relevant.

After all, the matrix cannot provide a detailed budget-like expenditure plan for adaptation in the coming decades. It can just serve as a first rough insight into expected costs, partly based on best-guess-results.

\section{A.2.4 The division into impact sectors}

The presented adaptation costs are partitioned into different impact fields, as most adaptation measures are to reduce damages in specific sectors and can therefore be assigned to these sectors.

Special attention should be paid to the cross section sector "Weather Extremes". The literature cited in the matrix refers primarily to costs arising from adaptation of the constructed infrastructure, i.e. making the structures resilient to extreme weather events. These costs are 
hardly attributable to any impact sector. At the same time, they are quite high, e.g. up to an annual value of 50.9 billion $€$ in the 2060s for Western Europe (Bosello et al. 2009).

By the partition into different impact sectors the matrix provides a first insight into the current state of research of adaptation costs. It becomes clear that to date most cost estimates refer to coastal protection. It should not be derived, however, that this is the sector with the highest costs. It is just saying that here the impacts and adaptation techniques are quite well studied and the costs are well known, given an assumption for the future sea-level rise. In fact, the global adaptation cost study of UNFCCC (2007) estimates the costs of coastal protection in 2030 at a comparably low level. Adaptation in other fields like agriculture, forestry, fisheries, ecosystems, and - most outstanding - infrastructure will be much costlier, according to this source. However, these estimates come with a high level of uncertainty, whereas the knowledge of coastal protection costs is relatively well developed. On the other side, by comparing the sector-specific entries of coastal protection one can see a wide range of results even in that best-established research field. For great parts the differences can be reasoned by different assumptions regarding the sea-level rise or protection level, which is then indicated in the "Scenario" column.

The last column named "Total" contains results of studies not focussing on specific sectors, but on the total impact of adaptation costs on social welfare. There are only very few studies available which try to aggregate adaptation costs throughout the total economy. In principal, we can also sum up the entries of one line in the matrix to calculate the direct costs of adaptation in the analysed sectors and thereby yield an approximate value for total direct adaptation costs in the economy. A prerequisite of this addition would be the use of identical scenarios, regional and time coverage, division into impact sectors and methods. Thus, the data actually do not allow a reasonable addition of single values due to lack of comparable results. Note that additional indirect effects mentioned in the introductory section are completely neglected if we just added up the different sector impacts.

\section{A.2.5 Exchange rates and inflation}

The numerical entries in the matrix are - if not indicated otherwise - annual adaptation costs in million $€$, in prices of 2005, and thereby comparable in terms of currency and price levels. The column named "Exchange and inflation" gives the original value found in primary literature and the calculation to $€$ in prices of 2005. For the translation of USD into $€$ we used the average market exchange rate of the year of the respective study. 
In a second step, we adjusted for price level changes. E.g., the construction of a dike in the year 2000 will be more expensive than the same dike constructed in 1990. To make both estimates comparable, we used price indices to standardise all figures to prices of 2005. For capital-intensive adaptation in studies about one specific country it appears reasonable to apply national price indices for capital formation. For adaptation measures not sufficiently concretised we used the national GDP price indices. For studies with European coverage we applied equivalent price indices for the $€$-area as an approximation for the price level changes in the studied area. 